\title{
Hydrodynamic coupling in microbially mediated fracture mineralization: Formation of self-organized groundwater flow channels
}

\author{
Gráinne El Mountassir, ${ }^{1}$ Rebecca J. Lunn, ${ }^{1}$ Heather Moir, ${ }^{1}$ and Erica MacLachlan ${ }^{1}$ \\ Received 22 January 2013; revised 8 November 2013; accepted 16 November 2013; published 6 January 2014.
}

[1] Evidence of fossilized microorganisms embedded within mineral veins and mineral-

filled fractures has been observed in a wide range of geological environments.

Microorganisms can act as sites for mineral nucleation and also contribute to mineral precipitation by inducing local geochemical changes. In this study, we explore fundamental controls on microbially induced mineralization in rock fractures. Specifically, we systematically investigate the influence of hydrodynamics (velocity, flow rate, and aperture) on microbially mediated calcite precipitation. Our experimental results demonstrate that a feedback mechanism exists between the gradual reduction in fracture aperture due to precipitation, and its effect on the local fluid velocity. This feedback results in mineral-fill distributions that focus flow into a small number of self-organizing channels that remain open, ultimately controlling the final aperture profile that governs flow within the fracture. This hydrodynamic coupling can explain field observations of discrete groundwater flow channeling within fracture-fill mineral geometries where strong evidence of microbial activity is reported.

Citation: El Mountassir, G., R. J. Lunn, H. Moir, and E. MacLachlan (2014), Hydrodynamic coupling in microbially mediated fracture mineralization: Formation of self-organized groundwater flow channels, Water Resour. Res., 50, 1-16, doi:10.1002/2013WR013578.

\section{Introduction}

[2] Microorganisms are known to mediate many geochemical processes [Konhauser, 2007; Gadd, 2010] and given the wide variation in composition of bulk fluid in different geological environments, microbes can induce precipitation of a whole range of different mineral precipitates including metal oxides, carbonates, phosphates, sulfates, and sulfides [Gollapudi et al., 1995; Konhauser, 2007]. Microbes are abundant in groundwater and geological media, and have even been found in rocks at depth where energy sources are sparse [e.g., Brown et al., 1994; Pedersen et al., 1996, 1997]. In hard rock environments, mineral precipitation is commonly observed in discontinuities at all scales, from mineralization in faults and fracture zones, to individual discrete fractures, fissures, and joints [e.g., Segall and Pollard, 1983; Heath, 1985], and hence plays a significant role in controlling fluid flow at depth.

[3] Evidence of fossilized microorganisms embedded within mineral-filled fractures has been observed in calcite precipitates formed at depth: in calcite-filled veins in

Additional supporting information may be found in the online version of this article.

${ }^{1}$ Department of Civil and Environmental Engineering, University of Strathclyde, Glasgow, UK.

Corresponding author: G. El Mountassir, Department of Civil and Environmental Engineering, University of Strathclyde, John Anderson Building, 107 Rottenrow, Glasgow G4 0NG, UK. (grainne.elmountassir@strath.ac.uk)

(C)2013. American Geophysical Union. All Rights Reserved. 0043-1397/14/10.1002/2013WR013578
Devonian rocks [Trewin and Knoll, 1999], in fractures in a Jurassic oolitic limestone [Rubert et al., 2009], and in fractures in diorite sampled at $450 \mathrm{~m}$ depth [Heim et al., 2012]. Microorganisms can act as chemically reactive sites for the sorption of metal ions due to negative charges on their cell surfaces, which can then lead to nucleation and mineral precipitation [Beveridge and Doyle, 1989; Konhauser, 2007; Gadd, 2010]. Microorganisms can also play a more critical role by creating the local geochemical conditions necessary for mineral precipitation to occur, for example, by increasing $\mathrm{pH}$ leading to increased mineral saturation and subsequent precipitation [Mitchell and Ferris, 2006]. Pedersen et al. [1997] present evidence of fossilized microbes embedded within calcite precipitate coating a granodiorite fracture surface, sampled from a depth of $207 \mathrm{~m}$. Stable isotope analysis shows that the bicarbonate was biogenically produced, indicating strong microbial involvement in the precipitation process. Budai et al. [2002] also present evidence of bacterial processes (methane generation and oxidation) contributing to calcite precipitation within filled fractures in the Devonian Antrim Shale, USA, based on unusually high and unusually low values of $\delta 13 \mathrm{C}$.

[4] As well as interest in natural systems, there is motivation to understand biogeochemical processes for the purpose of engineering alterations in the subsurface. Microbially induced calcite precipitation has been relatively well studied in this regard; for soil stabilization [DeJong et al., 2006; Whiffin et al., 2007; Van Paassen et al., 2010; Harkes et al., 2010], for enhanced oil recovery [Ferris et al., 1996], for $\mathrm{CO}_{2}$ sequestration [Cunningham et al., 2009; Mitchell et al., 
2010; Phillips et al., 2013], for solid-phase capture of contaminants [Fujita et al., 2008], for repairing microcracks in concrete [Bang et al., 2001; Van Tittelboom et al., 2010; De Muynck et al., 2010] and for permeability reduction in fractured rock [Cuthbert et al., 2013]. A common feature of these engineered studies is the need for periods of no flow, which promote bacterial attachment and calcite precipitation. One study using a flowing system [Stoner et al., 2005] showed that calcite precipitation is also enhanced in regions with very low fluid velocities.

[5] The objective of this study was to investigate the influence of hydraulic controls (velocity, flow rate, aperture) on the spatial distribution of microbially mediated mineral precipitation within fractures using flocculated bacteria. Flocculation of bacteria was induced resulting in microbial suspensions with a range of floc sizes from single cells up to larger flocs. A case study of microbially induced calcite precipitation was used, as a model biomineralization system. This study contributes to a deeper understanding of the fundamental controls on microbially mediated mineral precipitation, which is important for the further advancement of fracture flow models and the potential development of engineered biomineralization strategies.

\section{Microbially Induced Calcite Precipitation}

[6] The biomineralization process investigated in this study is microbially induced calcite precipitation via urea $\left(\mathrm{CO}\left(\mathrm{NH}_{2}\right)_{2}\right)$ hydrolysis. This process relies on a bacterium hydrolyzing urea into ammonia and carbonic acid (equation (1)). This is followed by the production of ammonium ions and an increase in the $\mathrm{pH}$ surrounding the bacterial cell, due to the net production of $\mathrm{OH}^{-}$ions (equation (2)). As the $\mathrm{pH}$ increases, carbonic acid $\left(\mathrm{H}_{2} \mathrm{CO}_{3}\right)$ is converted to bicarbonate ions $\left(\mathrm{HCO}_{3}{ }^{-}\right)$(equation (3)), subsequently forming carbonate ions $\left(\mathrm{CO}_{3}{ }^{2-}\right)$ (equation (4)). In the presence of calcium ions, the increase in $\mathrm{pH}$ promotes the precipitation of calcium carbonate $\left(\mathrm{CaCO}_{3}\right)$ (equation (5)) [Ferris et al., 1992, 1996; Mitchell et al., 2010].

$$
\begin{gathered}
\left.\mathrm{CO}\left(\mathrm{NH}_{2}\right)_{2}+2 \mathrm{H}_{2} \mathrm{O} \rightarrow 2 \mathrm{NH}_{3}+\mathrm{H}_{2} \mathrm{CO}_{3} \text { (urea hydrolysis }\right) \\
2 \mathrm{NH}_{3}+2 \mathrm{H}_{2} \mathrm{O} \leftrightarrow 2 \mathrm{NH}_{4}{ }^{+}+2 \mathrm{OH}^{-}(\mathrm{pH} \text { increase }) \\
\mathrm{H}_{2} \mathrm{CO}_{3}+2 \mathrm{OH}^{-} \leftrightarrow \mathrm{HCO}_{3}{ }^{-}+\mathrm{H}_{2} \mathrm{O}+\mathrm{OH}^{-} \\
\mathrm{HCO}_{3}{ }^{-}+\mathrm{H}_{2} \mathrm{O}+\mathrm{OH}^{-} \leftrightarrow \mathrm{CO}_{3}{ }^{--}+2 \mathrm{H}_{2} \mathrm{O} \\
\mathrm{Ca}^{2+}+\mathrm{CO}_{3}{ }^{2-} \rightarrow \mathrm{CaCO}_{3}(\mathrm{~s}) \text { (calcite precipitation) }
\end{gathered}
$$

[7] Sporosarcina pasteurii (S. pasteurii, strain ATCC 11859), a gram-positive, spore-forming, ureolytic bacterium was used in this study to induce calcite precipitation as this model bacterium has been well studied in the laboratory [e.g., Gollapudi et al., 1995; Ferris et al., 2003; Mitchell and Ferris, 2006; Whiffin et al., 2007; Tobler et al., 2011].

[8] The rate of calcite $\left(\mathrm{CaCO}_{3}\right)$ precipitation is controlled by four main parameters; the calcium concentration, the concentration of dissolved inorganic carbon (DIC) as produced by ureolysis (equations (1-5)), the $\mathrm{pH}$, and the availability of nucleation sites [Hammes and Verstraete, 2002]. $\mathrm{CaCO}_{3}$ precipitation requires the presence of sufficient calcium and carbonate ions such that the ion activity product (IAP) exceeds the solubility constant (Kso) leading to the solution becoming supersaturated with respect to calcium carbonate. The concentration of carbonate ions is related to the concentration of DIC and the $\mathrm{pH}$ of the environment. Microbial metabolic activity influences both these factors, as well as the bacteria providing nucleation sites [DeMuynck et al., 2010].

[9] Classical nucleation theory assumes that nucleation on surfaces (termed "heterogeneous nucleation") is energetically more favorable than nucleation within a uniform phase (termed "homogeneous nucleation") [Cheong et al., 2013]. Microbial cell surfaces are thought to reduce the nucleation activation energy barrier, which must be overcome for nucleation by providing chemically reactive sites for sorption [Ferris et al., 2003; Gadd, 2010]. S. pasteurii is a grampositive bacterium; its cell walls are composed of peptidoglycan with secondary polymers of teichoic acids, which give rise to electronegative charges on the cell surface [SchultzeLam et al., 1996]. These negative charges attract positively charged ions (cations), such as calcium ions. Once the cation has complexed with the bacterial cell, it can serve as a nucleation site, enabling calcite mineralization on the cell surface [Schultze-Lam et al., 1996; Stocks-Fischer et al., 1999].

[10] Homogeneous nucleation is also known to occur in solutions where geochemical changes have been induced by S. pasteurii. Mitchell and Ferris [2006] demonstrated that calcite crystals were precipitated in both bacteriainclusive and bacteria-free environments, which had access to the same artificial groundwater solution (the two environments were separated by a cellulose dialysis membrane). This study highlighted that nucleation of calcite can proceed in the absence of $S$. pasteurii, although their presence in the bacteria-inclusive solution increased both the size and size variance of the resulting crystals, and led to a greater crystal growth rate throughout the experiments, relative to the bacteria-free solution.

[11] In this study, the influence of hydraulic controls on the spatial distribution of microbially induced calcite precipitation was investigated, for artificial rock fractures, using bacteria-inclusive solutions.

\section{Bacterial Transport Mechanisms}

[12] The form in which bacteria are present in solution affects their transport through fracture networks. In particular, where bacteria exist in deep groundwater, fluid geochemistry, and microbe-mineral interactions can result in the formation of bacterial flocs [Juniper et al., 1995], albeit in considerably lower concentrations than in surface environments. Over sufficiently long time scales bacterial sedimentation can be a significant transport mechanism within the natural environment [Wan et al., 1995; Inoue et al., 2007], and as observed in surface environments [e.g., Droppo, 2004; Droppo et al., 2007], flocculation promotes the process of sedimentation. The terminal settling velocity $\left(\mathrm{U}_{\mathrm{s}}\right)$ for porous microbial flocs can be approximated using Stoke's law, [Johnson et al., 1996; Li and Yuan, 2002]:

$$
U_{s}=\left[\frac{g f\left(\rho_{c}-\rho_{l}\right) W_{d}}{3 \pi \mu \rho_{c} d}\right]
$$

where the Reynolds number of the falling aggregate is $<1$ $\left(\operatorname{Re}_{\mathrm{a}}=\rho_{\mathrm{l}} \mathrm{U}_{\mathrm{s}} \mathrm{d} / \mu\right), \mathrm{g}$ is the acceleration due to gravity, $\mathrm{f}$ is a 
ratio of the wet mass of cells to the dry mass of cells, $\rho_{\mathrm{c}}$ is the density of the microbial cell, $\rho_{1}$ is the density of the fluid, $\mathrm{W}_{\mathrm{d}}$ is the dry mass of an individual microbial floc, $\mathrm{d}$ is the diameter of the microbial floc, and $\mu$ is the fluid viscosity. Stoke's law therefore implies that the settling velocity is proportional to the floc diameter squared (since $\mathrm{W}_{\mathrm{d}}$, is proportional to the floc diameter cubed). Wan et al. [1995] illustrated that the time taken for terminal settling velocities to be reached is very small for bacterial sedimentation, occurring over very short distances. It is therefore highly likely that the terminal settling velocities of the flocs were reached in our experiments. Other deposition and mobilization mechanisms also exist for flocs and individual microbes, for example surface attachment due to electrostatic forces, shear mobilization, and straining [DeNovio et al., 2004]. This study investigated the role of all of these processes in determining the spatial distribution of microbially induced calcite precipitation on the surface of rock fractures.

\section{Experimental Methods}

\subsection{Experimental Setup}

[13] Microbially induced calcite precipitation was investigated in fractures of varying widths and apertures. The terms fracture width and fracture aperture are defined in Figure 1 and are used consistently throughout the paper. Fracture flow cells were constructed using two sheets of transparent polycarbonate. Lexan 9030 polycarbonate was used to manufacture the flow cells. Lexan polycarbonate is hydrophobic with a water contact angle of $76^{\circ}$ [Gil'man et al., 2003]. Polycarbonates exhibit a negative surface charge when in contact with salt solutions for a wide range of $\mathrm{pH}$ (pH 4-10) [Kirby and Hasslebrink, 2004].

[14] Polycarbonate fracture flow cells of length $20 \mathrm{~cm}$ and width $14 \mathrm{~cm}$ were used to enable visual observation of microbially induced calcite precipitation on the fracture surfaces over time. Each flow cell comprised a smooth top sheet (Figure 1a) and a lower etched sheet designed to represent more than one fracture (Figure 1b). The fracture flow cells were manufactured using a precision computer numerical control (CNC) milling machine which has an operating tolerance of $\pm 5 \mu \mathrm{m}$. Flow Cell 1 had eight fractures all with different widths and apertures (Figure 1c). Flow Cell 2 consisted of five etched fractures all of which had an aperture of $0.3 \mathrm{~mm}$ but were of varying width (Figure 1d). Figure 1e shows a schematic of the experimental setup. Calcite precipitation within the fractures was monitored over time using a Canon Powershot G9 camera. The fracture flow cells were in the horizontal position in all of the experiments presented here, with the digital camera mounted above the flow cells (Figure 1e) at a distance of $425 \mathrm{~mm}$, allowing the full fracture flow cell to be photographed at a resolution of 12.1 megapixels. Reflection from the upper polycarbonate surface was minimized using a Hoya $58 \mathrm{~mm}$ circular polarizing filter. Digital photographs were taken every $15 \mathrm{~s}$ during each injection cycle.

\subsection{Fracture Flow Velocities}

[15] The initial average flow velocity in each individual fracture at the beginning of each experiment, $v_{i}$, i.e., prior to any calcite precipitation, was calculated as: $\mathrm{v}_{\mathrm{i}}=\mathrm{Q} / \mathrm{A}$, where $\mathrm{Q}$ is the flow rate and $\mathrm{A}_{\mathrm{i}}$ the initial cross-sectional area of each fracture $(\mathrm{A}=$ width $\times$ aperture). For Flow Cell 1, Fractures 1 to 3 had the same $A_{i}$ and thus for a given $\mathrm{Q}$ the same $\mathrm{v}_{\mathrm{i}}$; Fractures 4 to 6 had half that $\mathrm{v}_{\mathrm{i}}$ and Fractures 7 and 8 half that $v_{i}$ again. At the velocities tested here, the Reynolds numbers of the fractures investigated in Flow Cells 1 and 2 remained well within the laminar flow regime $(\operatorname{Re}<100)$. The initial average fracture velocities in our experimental fractures ranged from $1 \times 10^{-3}$ to $149 \times$ $10^{-3} \mathrm{~m} / \mathrm{s}$ for apertures ranging from 100 to $500 \mu \mathrm{m}$, which corresponds to hydraulic gradients of 0.005 and above; the higher end of the spectrum found in the subsurface. Although high, such gradients are not unusual. Hydraulic gradients in the interval $0.01-0.1 \mathrm{~m} / \mathrm{m}$ have been reported for Swedish crystalline bedrock [Nordqvist et al., 2008] and moderate $(0.015)$ to large hydraulic gradients of 0.15 and above were reported below Yucca Mountain [Fridrich et al., 1994].

\subsection{Microbial Suspensions}

[16] In order to achieve traceable mineral precipitation reactions in the laboratory, concentrations of solutions needed to be increased relative to natural geological systems. As a consequence, microbial solutions used in the experiments had much higher concentrations of bacterial cells than would typically be encountered in groundwater systems, in which $10^{5}-10^{6}$ cells $/ \mathrm{mL}$ have been observed [Konhauser, 2007]. The optical density (OD) of the microbial suspensions was measured using a spectrophotometer (Thermo Scientific Helios Zeta ultraviolet-visible (UVVIS) model) at a fixed wavelength of $600 \mathrm{~nm}\left(\mathrm{OD}_{600}\right)$. This is a common method of ensuring that similar numbers of cells are present in prepared solutions of the same optical density. There is a linear relationship between OD and bacterial cell concentration, although the relationship tends to deviate from linear at high ODs [Hogg, 2013], it is a useful means of comparing different bacterial solutions. Two microbial suspensions were deployed in this study, with $\mathrm{OD}_{600}$ of 1.0 and 0.25 , which correspond to bacterial concentrations of approximately $10^{7}$ and $10^{8}$ cells $/ \mathrm{mL}$, respectively, equivalent to 2 orders of magnitude greater than typically observed in natural groundwater. Table 1 presents details of the preparation of the microbial suspensions.

[17] Data are rare, but given the frequent presence of fine-grained material (clay particles) within rock fractures [Abelin et al., 1985; Zimmerman and Main, 2004] and the ubiquitous nature of microbial populations at depth [e.g., Pedersen et al., 1996, 1997; Pedersen, 1997] it is likely that bacteria exist in a range of forms from individual cells to large flocs. To control the distribution of floc sizes within the microbial suspensions, flocculation was induced prior to injection into the fracture flow cells by mixing with $50 \mathrm{mM} \mathrm{CaCl} 2$. The introduction of $\mathrm{CaCl}_{2}$ leads the positive calcium ions to be attracted to the surface of the bacteria, reducing the double diffuse layer [Derjaguin and Landau, 1941 ; Verwey and Overbeek, 1948], and therefore reducing the repulsive forces between bacterial cells; they are thus more likely to approach more closely and flocculate. Additionally, increasing divalent cation concentration has been found to increase the concentration of exocellular protein bound to a bacterial cell; experiments suggest that these bound proteins are closely associated with the flocculation 


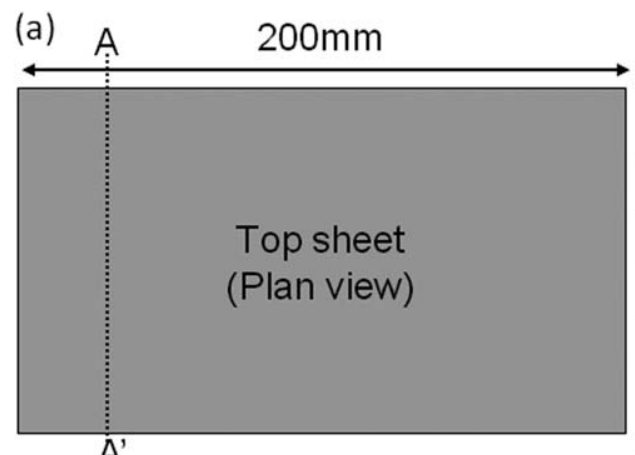

\begin{tabular}{|c|c|c|c|c|c|c|c|c|}
\hline \multicolumn{9}{|c|}{ Cross-section of Flow Cell 1} \\
\hline Fracture & 8 & 7 & 6 & 5 & 4 & 3 & 2 & 1 \\
\hline Width , w (mm) & 20 & 6.7 & 10 & 3.3 & 2.0 & 5.0 & 1.7 & 1.0 \\
\hline Aperture, b (mm) & 0.1 & 0.3 & 0.1 & 0.3 & 0.5 & 0.1 & 0.3 & 0.5 \\
\hline (d) & \multicolumn{8}{|c|}{ 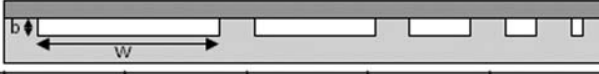 } \\
\hline Fracture & 5 & & 4 & & & 2 & & 1 \\
\hline Width, w (mm) & 30 & & 20 & & & 5 & & 2 \\
\hline Aperture, b (mm) & 0.3 & & 0.3 & & & 0.3 & & 0.3 \\
\hline
\end{tabular}

(b) $A$

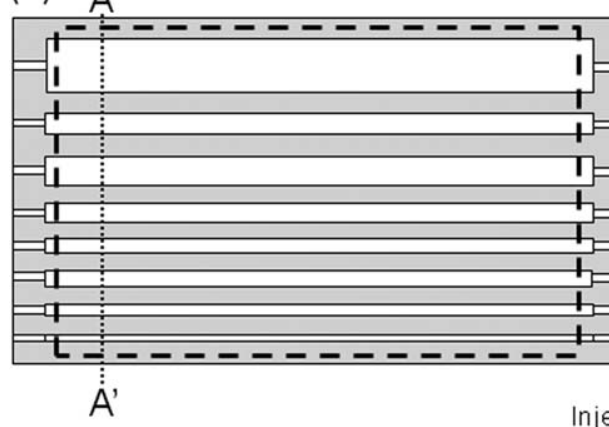

(e)

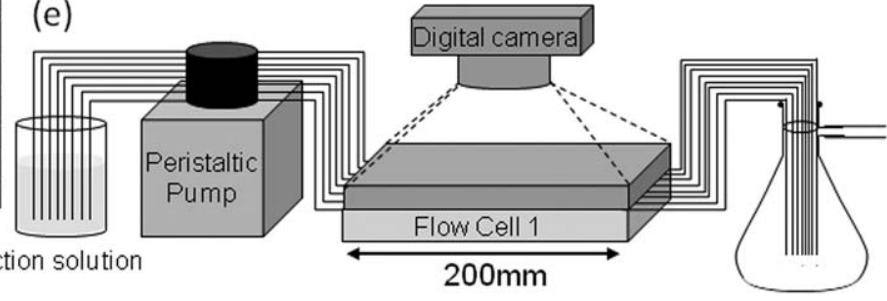

\section{Etched Lower sheet (Plan view)}

Figure 1. Experimental setup: (a) plan view of top polycarbonate sheet, (b) plan view of lower etched polycarbonate sheet, (c) cross section of fractures of different widths and apertures in Flow Cell 1 (vertical exaggeration of apertures is 10X), (d) cross section of fractures of different widths and apertures in Flow Cell 2 (vertical exaggeration of apertures is 10X), and (e) schematic of flow arrangement.

of bacteria [Higgins and Novak, 1997; De Schryver et al., 2008].

[18] The addition of $\mathrm{CaCl}_{2}$, to induce bacterial flocculation prior to injection, allowed for control and observation of the initial floc size distribution. The distributions of the bacterial flocs present in the two microbial suspensions $\left(\mathrm{OD}_{600}=1.0\right.$ and $\left.\mathrm{OD}_{600}=0.25\right)$ prior to injection into the flow cells, were investigated using a microscope (Olympus BX60) under a bright field. The captured images were analyzed using ImageJ software to obtain the area of each individual floc, from which floc diameters were calculated (assuming the flocs are spherical) [Li and Yuan, 2002]. Figure 2 shows the form of an individual large $S$. pasteurii floc, a range of other floc sizes and the presence of individual cells in the $1.0 \mathrm{OD}_{600}$ solution. The floc size distribution for both microbial suspensions was characterized by the parameters $d_{50}$ and $d_{90}$, which are the median and 90th percentile floc diameters. These were calculated as $\mathrm{d}_{50}=13 \mu \mathrm{m}, \mathrm{d}_{90}=170 \mu \mathrm{m}$ and $\mathrm{d}_{50}=9 \mu \mathrm{m}, \mathrm{d}_{90}=70 \mu \mathrm{m}$ for the $1.0 \mathrm{OD}_{600}$ and $0.25 \mathrm{OD}_{600}$ microbial suspensions, respectively (using approximately 300 flocs for each). While single cells were observed in both suspensions, the median percentile floc diameter $\left(\mathrm{d}_{50}\right)$ was only slightly larger for the $1.0 \mathrm{OD}_{600}$ suspension. The greatest variation between the two suspensions was the $d_{90}$ parameter which indicates that much larger flocs were present in the 1.0 $\mathrm{OD}_{600}$ suspension than in the $0.25 \mathrm{OD}_{600}$ suspension.

\subsection{Flow Injection Strategy}

[19] In these experiments, the aim was to investigate the evolution of microbially induced calcite precipitation using flocculated bacteria over time in flowing systems. Recent

Table 1. Summary of Preparation and Constituents of Injection Solutions

\begin{tabular}{|c|c|c|}
\hline Solution & Preparation & Constituents \\
\hline \multirow[t]{3}{*}{$\begin{array}{l}\text { Microbial } \\
\text { suspension }\end{array}$} & $\begin{array}{l}\text { Sporosarcina pasteurii cultured on agar } \\
\text { (Brain Heart Infusion with } 2 \% \text { urea) }\end{array}$ & Equal volumes of $S$. pasteurii solution $+50 \mathrm{mM} \mathrm{CaCl}_{2}$ \\
\hline & Grown overnight in Brain Heart Infusion (with $2 \%$ urea) & Final Optical Density at $600 \mathrm{~nm}\left(\mathrm{OD}_{600}\right)=1.0$ or 0.25 \\
\hline & $\begin{array}{c}\text { Bacterial separation by vacuum filtration (Flow Cell 1) } \\
\text { and centrifuging (Flow Cell 2) }\end{array}$ & $\mathrm{pH}$ adjusted to 6.5 using $10 \% \mathrm{HCl}$ \\
\hline \multirow{2}{*}{$\begin{array}{l}\text { Cementation } \\
\text { solution }\end{array}$} & Autoclave $\mathrm{CaCl}_{2}$ solution & $0.7 \mathrm{MCaCl}_{2}+\mathrm{CO}\left(\mathrm{NH}_{2}\right)_{2}$ \\
\hline & Sterile injection of $40 \%$ urea solution passing a $0.2 \mu \mathrm{m}$ filter & $\mathrm{pH}$ adjusted to $6.5 \mathrm{using} 10 \% \mathrm{HCl}$ \\
\hline
\end{tabular}




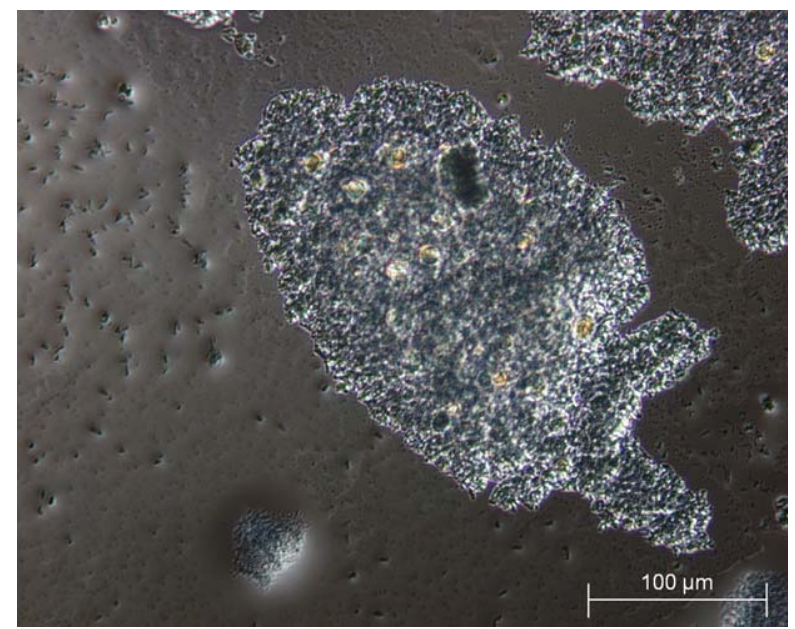

Figure 2. Optical microscope image of large microbial floc, a range of other floc sizes, and the presence of individual cells in the $1.0 \mathrm{OD}_{600}$ microbial suspension.

research has illustrated that $S$. pasteurii can become completely encased in calcite, limiting subsequent precipitation [Cuthbert et al., 2012; Tobler et al., 2012], for this reason a repeated bacterial injection strategy was adopted in these experiments. Prior to each injection cycle, the flow cells were initially saturated by flushing with water for a minimum of $30 \mathrm{~min}$. The microbial suspension was immediately pumped into the flow cell after mixing. This was then followed by an injection of a $0.7 \mathrm{M} \mathrm{CaCl}_{2}$ and Urea solution, referred to here as the cementation solution (see Table 1). In terms of salt concentration, this simulates a deep saline water with total dissolved salt concentrations in the range of 10,000-100,000 mg/L [Metcalfe et al., 2007]. For these experiments, it was desirable to have a high availability of calcium ions and carbonate ions (produced via urea hydrolysis) in the system for calcite precipitation.

[20] Details of the experimental injection strategies are presented in Table 2. Two Gilson Minipuls (Model 3) peristaltic pumps were used for pumping the treatment solutions through the flow plates. Each channel on the peristaltic pumps was connected to an inlet port of an individual fracture in the plates. Each flow cell experiment was performed with the same flow rate in each individual fracture. Equal volumes of microbial suspension and cementa- tion solution were used within each injection cycle in all of the experiments. Injection of the microbial suspension, followed by an injection of cementation fluid, constitutes one injection cycle. For example, for Experiment 1 in Flow Cell 1, 33.6 mL of microbial suspension was injected into each fracture over a period of $30 \mathrm{~min}$, followed by an injection of $33.6 \mathrm{~mL}$ of cementation fluid into each fracture over $30 \mathrm{~min}$. This was repeated for five cycles. All of the experiments presented herein were carried out under continuous flow conditions; when the cells were not being injected with microbial or cementation solutions (generally overnight when image collection was not feasible), water was continuously pumped through the cells at the same flow rate to maintain flowing conditions, to minimize unobserved precipitation and ensure that equal volumes of microbial suspension and cementation fluid were injected per cycle.

\subsection{Scanning Electron Microscopy}

[21] On completion of Experiment 3, Flow cell 2 was opened and the calcite precipitate was sampled at 12 different locations using sticky carbon tabs (note minimal pressure was used to prevent any damage to the samples). These samples were then analyzed using a Zeiss Sigma field emission scanning electron microscope (SEM) with ionized nitrogen under low vacuum. As a result the specimens did not need to be coated prior to placing in the SEM. Backscattered (secondary) electron imaging was used to examine the calcite morphology. Energy-dispersive X-ray microanalysis (INCA mapping) was also carried out to determine composition.

\section{Experimental Results}

\subsection{Initial Observations}

[22] Figure 3 illustrates the temporal and spatial evolution of microbially induced calcite precipitation over a number of injection cycles in a single fracture (Fracture 5 of Flow Cell 2). The calcite can be visually observed since it precipitates as a white mineral. With each injection cycle, more calcite precipitates are located on the fracture surfaces. From examination of the surfaces at the end of each test, it was evident that the precipitates observed in Figure 3 were predominantly located on the lower fracture surface, although a thin layer of fine precipitate was present on all fracture surfaces. In Figure 3, we observed there to be more

Table 2. Flow Rate, $\mathrm{OD}_{600}$, Pumped Injection Volumes, Duration, and Number of Injection Cycles

\begin{tabular}{|c|c|c|c|c|c|c|c|c|c|c|}
\hline \multirow[b]{3}{*}{ Experiment } & \multirow[b]{3}{*}{$\begin{array}{l}\text { Flow } \\
\text { Cell }\end{array}$} & \multirow[b]{3}{*}{$\begin{array}{c}\text { Optical } \\
\text { Density of } \\
\text { Microbial } \\
\text { Suspension } \\
\left(\mathrm{OD}_{600}\right)\end{array}$} & \multirow[b]{3}{*}{$\begin{array}{l}\text { Flow Rate } \\
\text { Per Fracture } \\
\text { (mL/min) }\end{array}$} & \multicolumn{6}{|c|}{ One Injection Cycle } & \multirow[b]{3}{*}{$\begin{array}{l}\text { No. of } \\
\text { Injection } \\
\text { Cycles }\end{array}$} \\
\hline & & & & \multicolumn{2}{|c|}{$\begin{array}{l}\text { Stage 1: Injection of } \\
\text { Microbial Suspension }\end{array}$} & \multicolumn{4}{|c|}{ Stage 2: Injection of Cementation Fluid } & \\
\hline & & & & $\begin{array}{c}\text { Volume } \\
\text { Injected Per } \\
\text { Fracture }(\mathrm{mL})\end{array}$ & $\begin{array}{l}\text { Duration } \\
\text { (min) }\end{array}$ & $\begin{array}{c}\text { Volume } \\
\text { Injected Per } \\
\text { Fracture }(\mathrm{mL})\end{array}$ & $\begin{array}{l}\text { Duration } \\
\text { (min) }\end{array}$ & $\begin{array}{c}\text { Mass of } \mathrm{CaCl}_{2} \\
\text { Injected Per } \\
\text { Fracture }(\mathrm{g})\end{array}$ & $\begin{array}{c}\text { Mass of } \\
\mathrm{CO}\left(\mathrm{NH}_{2}\right)_{2} \\
\text { Injected Per } \\
\text { Fracture }(\mathrm{g})\end{array}$ & \\
\hline 1 & 1 & 1.0 & 1.12 & 33.6 & 30 & 33.6 & 30 & 2.61 & 1.41 & 5 \\
\hline 2 & 1 & 1.0 & 4.48 & 44.8 & 10 & 44.8 & 10 & 3.48 & 1.88 & 5 \\
\hline 3 & 2 & 1.0 & 1.2 & 36 & 30 & 36 & 30 & 2.80 & 1.51 & 5 \\
\hline $4 a$ & 2 & 0.25 & 1.2 & 36 & 30 & 36 & 30 & 2.80 & 1.51 & 25 \\
\hline $4 b$ & 2 & 0.25 & 0.6 & 18 & 30 & 18 & 30 & 1.40 & 0.76 & 10 \\
\hline
\end{tabular}



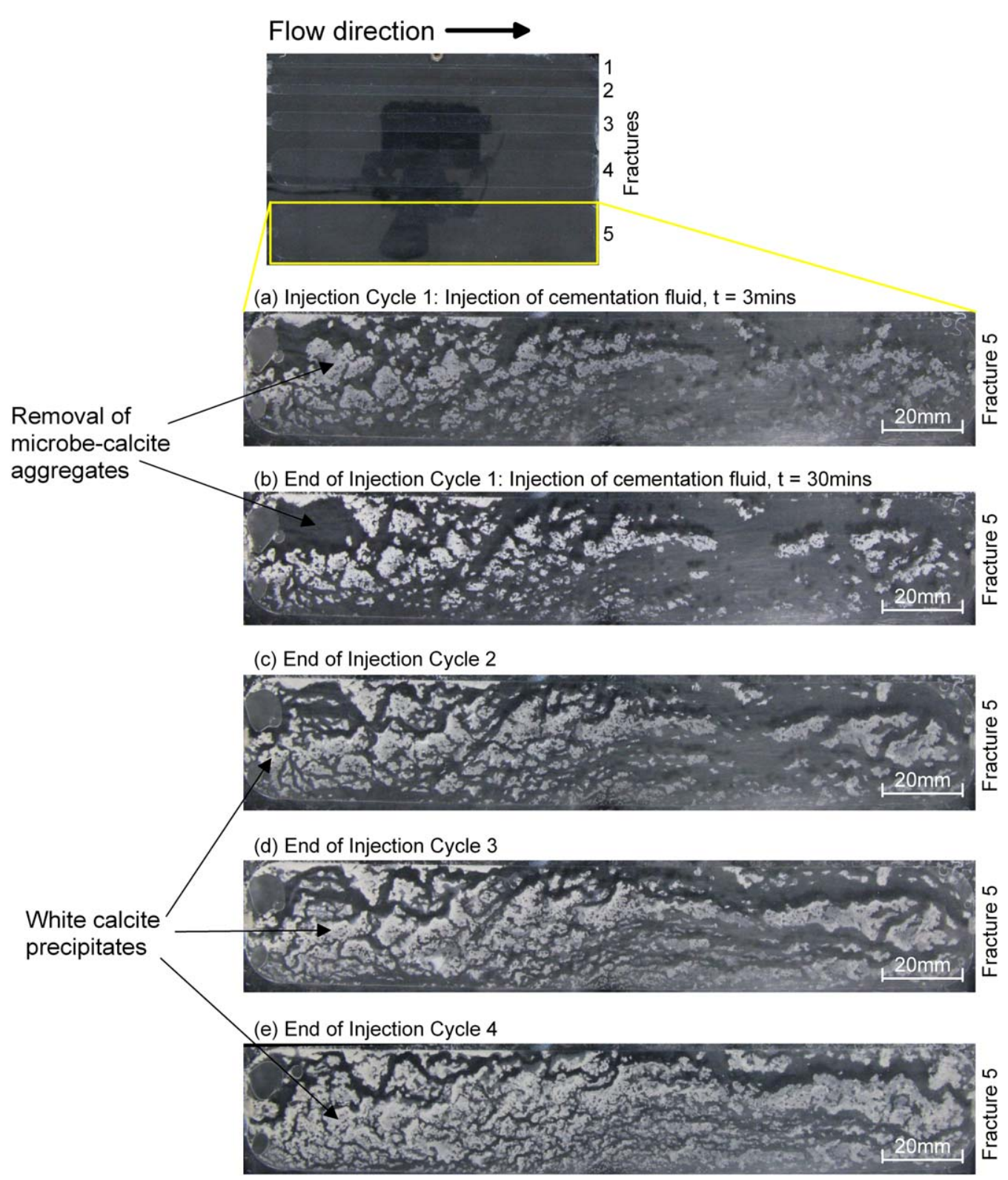

Figure 3. Evolution of microbially induced calcite precipitation in Fracture 5 of Flow Cell 2: Digital photographs (a) during the injection of cementation fluid ( $\mathrm{t}=3 \mathrm{mins})$ in Injection Cycle 1, (b) at the end of Injection Cycle 1 ( $\mathrm{t}=30 \mathrm{mins})$, (c) at the end of Injection Cycle 2, (d) at the end of Injection Cycle 3, and (e) at the end of Injection Cycle 4.

precipitates located close to the fracture inlets, with less located further along the fractures moving from left to right. Within this system the white calcite precipitates observed on the fracture surfaces of the flow cell, may be attributed to (a) calcite crystals which have grown from heterogeneous nucleation on fracture surfaces, (b) microbecalcite aggregates (i.e., heterogeneous nucleation on cell surfaces), and (c) homogeneous nucleation of calcite crystals in solution.

[23] Figure 3a is an image of Fracture 5 taken 3 min into the cementation injection of Injection Cycle 1 and Figure $3 \mathrm{~b}$ is taken at the end of Injection Cycle 1, i.e., after $30 \mathrm{~min}$ of injecting cementation fluid. By comparing Figures $3 \mathrm{a}$ and $3 \mathrm{~b}$ it becomes evident that, during a single cycle, some of the precipitates are deposited and then removed; this type of observation was associated with microbe-calcite aggregates, essentially mineralized flocs. A video of all five injection cycles in this experiment (Experiment 3, Table 2) was created using time-lapse photography and is included as supporting information. From visual observation (see supporting information video), it is evident that the transport of microbial flocs and calcite precipitates within, and indeed out of, the flow cell governs the eventual spatial distribution of the calcite precipitates on the fracture surfaces. Calcite precipitates may exit the flow cell as microbecalcite aggregates and as calcite crystals which formed in suspension; indeed there was a build up of calcite precipitation in the effluent container during these experiments. 
(a) Constant flow rate, $\mathrm{Q}=1.12 \mathrm{ml} / \mathrm{min}$

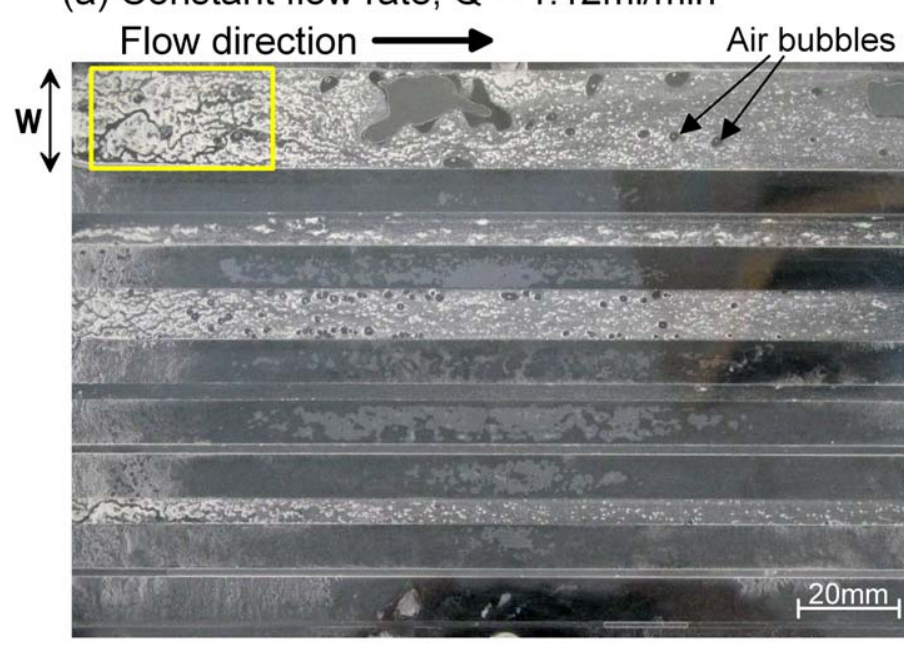

\begin{tabular}{|c|c|c|c|}
\hline Fracture & $\begin{array}{c}W \\
(\mathrm{~mm})\end{array}$ & $\begin{array}{c}\text { b } \\
(\mathrm{mm})\end{array}$ & $\begin{array}{c}v_{i} \\
\left(10^{-3} \mathrm{~m} / \mathrm{s}\right)\end{array}$ \\
\hline 8 & 20 & 0.1 & 9 \\
\hline 7 & 6.7 & 0.3 & 9 \\
\hline 6 & 10 & 0.1 & 19 \\
\hline 5 & 3.3 & 0.3 & 19 \\
\hline 4 & 2.0 & 0.5 & 19 \\
\hline 3 & 5.0 & 0.1 & 37 \\
\hline 2 & 1.7 & 0.3 & 37 \\
\hline 1 & 1.0 & 0.5 & 37 \\
\hline
\end{tabular}

(b) Constant flow rate, $\mathrm{Q}=4.48 \mathrm{ml} / \mathrm{min}$

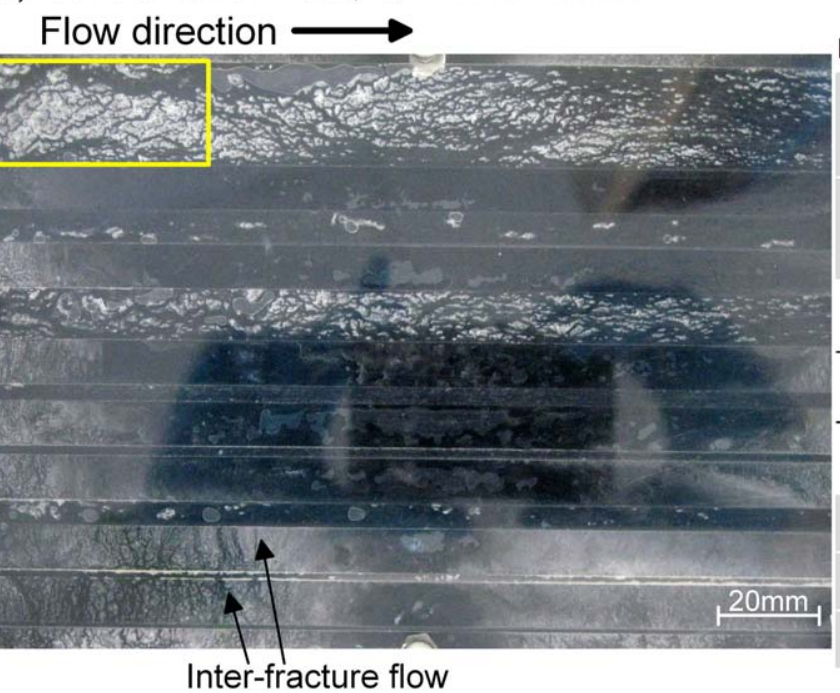

\begin{tabular}{|c|c|c|c|}
\hline Fracture & $\begin{array}{c}W \\
(m m)\end{array}$ & $\underset{(\mathrm{mm})}{\mathrm{b}}$ & $\begin{array}{c}v_{i} \\
\left(10^{-3} \mathrm{~m} / \mathrm{s}\right)\end{array}$ \\
\hline 8 & 20 & 0.1 & 37 \\
\hline 7 & 6.7 & 0.3 & 37 \\
\hline 6 & 10 & 0.1 & 75 \\
\hline 5 & 3.3 & 0.3 & 75 \\
\hline 4 & 2.0 & 0.5 & 75 \\
\hline 3 & 5.0 & 0.1 & 149 \\
\hline 2 & 1.7 & 0.3 & 149 \\
\hline 1 & 1.0 & 0.5 & 149 \\
\hline
\end{tabular}

Figure 4. Influence of velocity and aperture on calcite precipitation (Flow Cell 1) after five injection cycles at (a) $\mathrm{Q}=1.12 \mathrm{~mL} / \mathrm{min}$ and (b) $\mathrm{Q}=4.48 \mathrm{~mL} / \mathrm{min}$. W is the width of an individual fracture perpendicular to the flow direction and marked in Figure $4 \mathrm{a}, \mathrm{b}$ is the fracture aperture, and $\mathrm{v}_{\mathrm{i}}$ is the initial average fracture velocity, i.e., prior to precipitation. It should also be noted that the flow cell was not fully sealed between channels (see Figure $4 \mathrm{~b}$ ) and across cell flow was observed between fractures; the actual volume of across cell flow was very low, as each fracture was calibrated for the desired flow rate both prior to entering the fracture inlet and at the fracture outlet.

The focus of this investigation is on how the pattern of microbially induced calcite precipitation within the cell, evolves spatially and temporally on the fracture surfaces.

[24] In Figure 3, there is clear evidence of channeling and the formation of tortuous, braided pathways within the fracture as calcite is precipitated. The experiment (Experiment 3 ) presented in Figure 3 (and in the supporting information video) was carried out three times and similar braided patterns of channeling were observed consistently in each case, although the exact location and number of channels differed each time. Braiding, as observed here, is a common feature of sedimentation processes, for example, as observed in fluvial systems [e.g., Leopold and Wolman, 1957]. The next sections present results illuminating to what extent hydraulic controls (velocity, fracture aperture, and flow rate) influence the spatial distribution of calcite precipitates on the fracture surfaces.

\subsection{Influence of Velocity}

[25] Figure 4 presents the microbially induced calcite precipitation patterns observed in the fractures of Flow Cell 1 after five injection cycles using microbial suspensions with an $\mathrm{OD}_{600}=1.0$ at (a) a constant flow rate of $1.12 \mathrm{~mL} /$ $\mathrm{min}$ and (b) a constant flow rate of $4.48 \mathrm{~mL} / \mathrm{min}$ (Experiments 1 and 2 in Table 2). The widths (w) and aperture (b) of each fracture are noted on the figure, and the velocities indicated are the initial average flow velocities in each individual fracture, $\mathrm{v}_{\mathrm{i}}$ prior to any calcite precipitation. The area of each flow cell presented in the digital photographs in Figure 4 is defined by the dashed rectangle in Figure 1b. 
(a) $Q=1.12 \mathrm{ml} / \mathrm{min}$

(i)

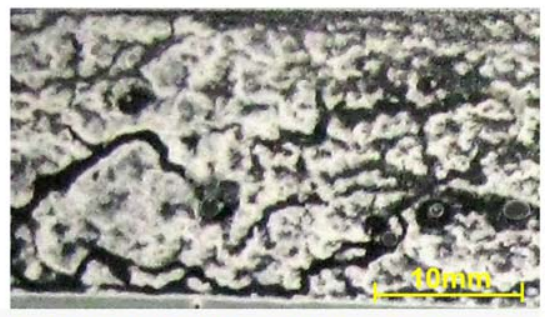

(ii)

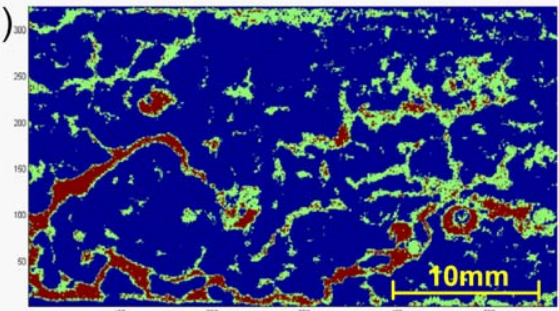

Initial fracture velocity $\sim 9 \mathrm{~mm} / \mathrm{s}$

Post-precipitation fracture velocity $\sim$ (b) $Q=4.48 \mathrm{ml} / \mathrm{min}$
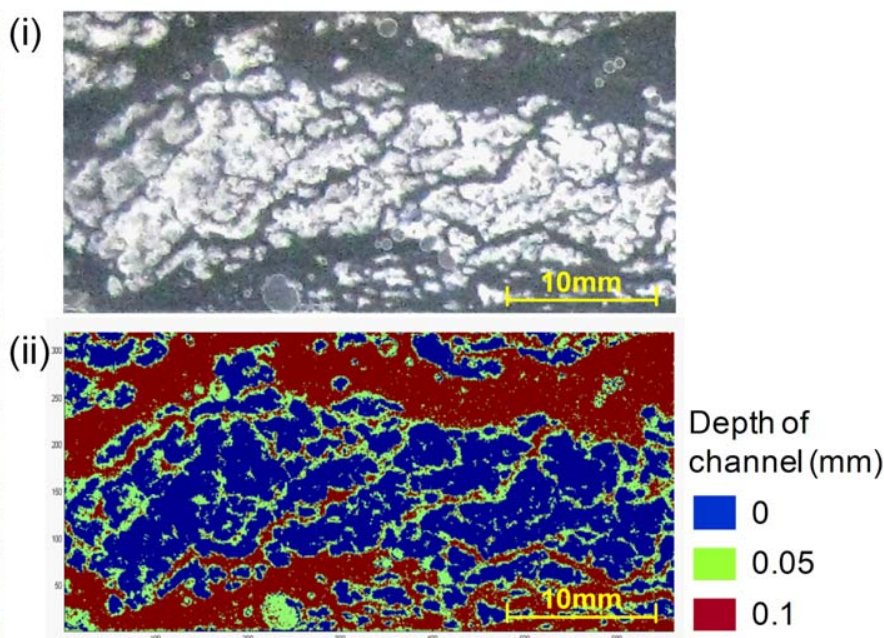

Initial fracture velocity $\sim 37 \mathrm{~mm} / \mathrm{s}$

Figure 5. Development of open faster flowing channels in Fracture 8 after five injection cycles at (a) $\mathrm{Q}=1.12 \mathrm{~mL} / \mathrm{min}$ and (b) $\mathrm{Q}=4.48 \mathrm{~mL} / \mathrm{min}$ : (i) digital photograph of areas in Fracture 8 marked on Figure 4, (ii) digital estimation of depth of calcite precipitation (image analysis conducted using Matlab), where blue indicates that the fracture is fully closed at that location (i.e., aperture $=0$ ), for the red channels the aperture is $0.1 \mathrm{~mm}$ (fully open) and for the green channels the aperture is $0.05 \mathrm{~mm}$.

[26] In Figure 4a, it is evident that similar channel-like patterns of precipitates were created in Fractures 3, 6, and 8 , where precipitation has reduced each fracture to a number of smaller tortuous pathways. Fractures 3, 6, and 8, all have the same aperture of $100 \mu \mathrm{m}$ and exhibited similar precipitation patterns, even at different velocities. The aperture influence can be explained by considering that the microbial flocs have the same vertical distance to travel in fractures of the same aperture before deposition onto the lower fracture surface in the flow cell, and therefore under creeping flow conditions $\left(\operatorname{Re}_{\mathrm{a}}<1\right)$, the settling time is equal.

[27] Figure $4 \mathrm{~b}$ shows the same experiment but with an increased flow rate of $4.48 \mathrm{~mL} / \mathrm{min}$. In this case, similar channelized flow paths were again observed in Fractures 6 and 8 , but channeling was no longer apparent in Fracture 3 at the higher initial fracture velocity of $149 \times 10^{-3} \mathrm{~m} / \mathrm{s}$. Furthermore, if we compare Fracture 6 from Figures 4a and $4 \mathrm{~b}$, it is clear that less calcite precipitate was present on the fracture surfaces at the higher fracture velocity (after five injection cycles), this is despite the fact that for $\mathrm{Q}=4.48$ $\mathrm{mL} / \mathrm{min}$, the mass of calcium chloride and urea injection per fracture during each cycle was one third greater than injected at $\mathrm{Q}=1.12 \mathrm{~mL} / \mathrm{min}$ (see Table 2). At the higher flow rate (Figure $4 b$ ), wider channels were maintained open compared to the lower flow rate (Figure $4 a$ ) in which the channels are narrower. Velocity clearly has an important influence on both the spatial distribution and the eventual mass of calcite that precipitates onto the fracture surfaces.

[28] Figure 5 shows a closer inspection of Fracture 8 postprecipitation for the areas marked with rectangles in Figures $4 \mathrm{a}$ and $4 \mathrm{~b}$. These detailed images were used to gain an approximate estimate of the magnitude of the fracture velocity in the remaining open channels. Image analysis was carried out using MatLab; using over 500 slices across each image to determine the new cross-sectional area of the fracture postprecipitation $\left(A_{p}\right)$. The average fracture velocity postprecipitation $\left(v_{p}\right)$ was then calculated as $Q / A_{p}$ Two categorization techniques were used to gauge the sensitivity of the velocity estimates to the technique applied; (i) categorizing each pixel of the image as being either open or closed depending on its gray scale value and (ii) using three categories for the channel: open, half open, or closed depending on its gray scale value (Figures 5aii and 5bii). Combining the results from both techniques, the velocity in the open channels was estimated to be in the range of $67 \times$ $10^{-3}$ to $110 \times 10^{-3} \mathrm{~m} / \mathrm{s}$ for a flow rate of $1.12 \mathrm{~mL} / \mathrm{min}$ and in the range of $81 \times 10^{-3}$ to $112 \times 10^{-3} \mathrm{~m} / \mathrm{s}$ for a flow rate of $4.48 \mathrm{~mL} / \mathrm{min}$. It is interesting to note that even though the patterns of precipitation vary; the velocity ranges for the open channels were of a similar magnitude. These observations lend support to the hypothesis that, as local velocities increase, shear velocities at fracture surfaces will exceed the actual settling velocity of the floc; then according to conventional theory on particle entrainment, all flocs will be entrained and deposition will be inhibited [Van Rijn, 1984].

\subsection{Bacterial Density (Concentration)}

[29] If the ratio of floc settling velocity to channel velocity is a key parameter governing the eventual location of calcite precipitates on the lower fracture surface, then the floc size should be an important variable: larger flocs should have higher settling velocities and hence settle out quicker for a given fracture velocity. The effect of different floc size distributions on microbially induced calcite precipitation was investigated in Flow Cell 2 where all the fractures had the same aperture of $300 \mu \mathrm{m}$ but had different 

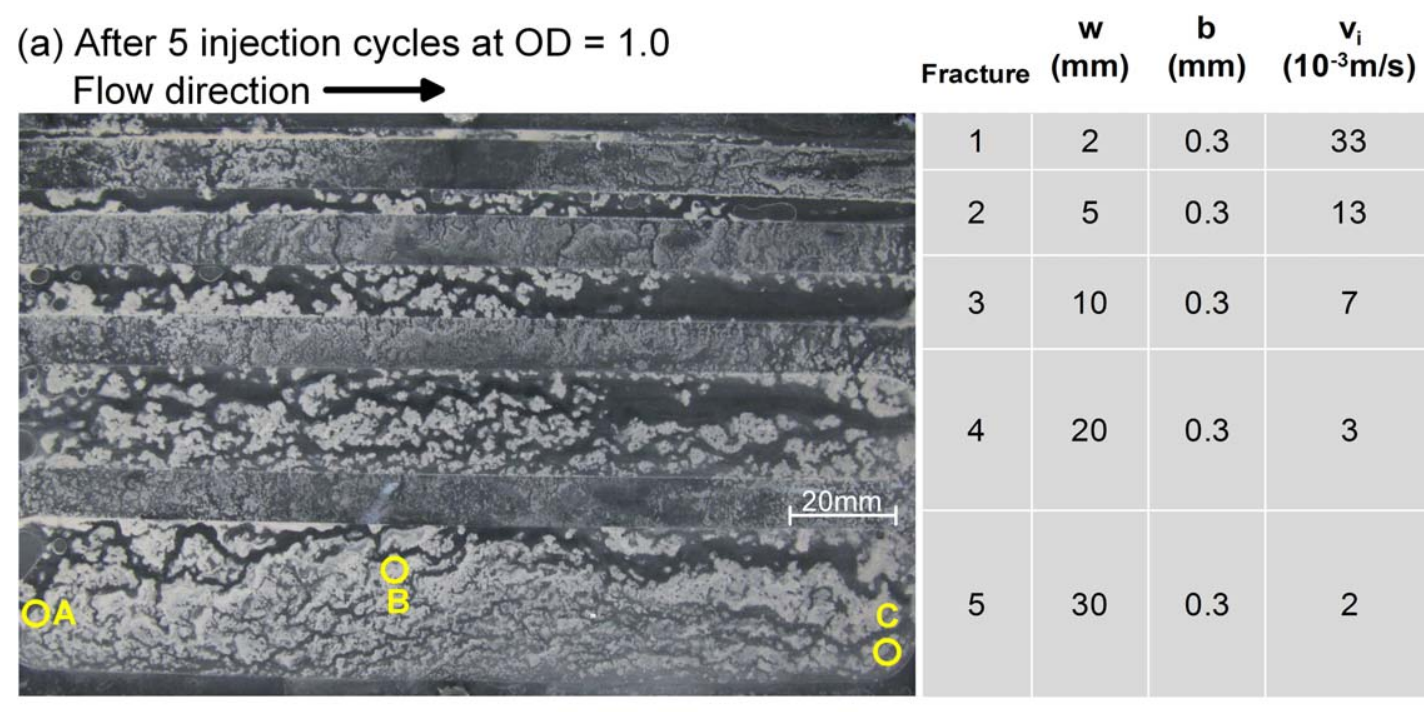

\begin{tabular}{|l|l|l|l|}
\hline 1 & 2 & 0.3 & 33 \\
\hline 2 & 5 & 0.3 & 13 \\
\hline 3 & 10 & 0.3 & 7 \\
\hline 4 & 20 & 0.3 & 3 \\
\hline & & & \\
\hline 5 & 30 & 0.3 & 2 \\
\hline
\end{tabular}
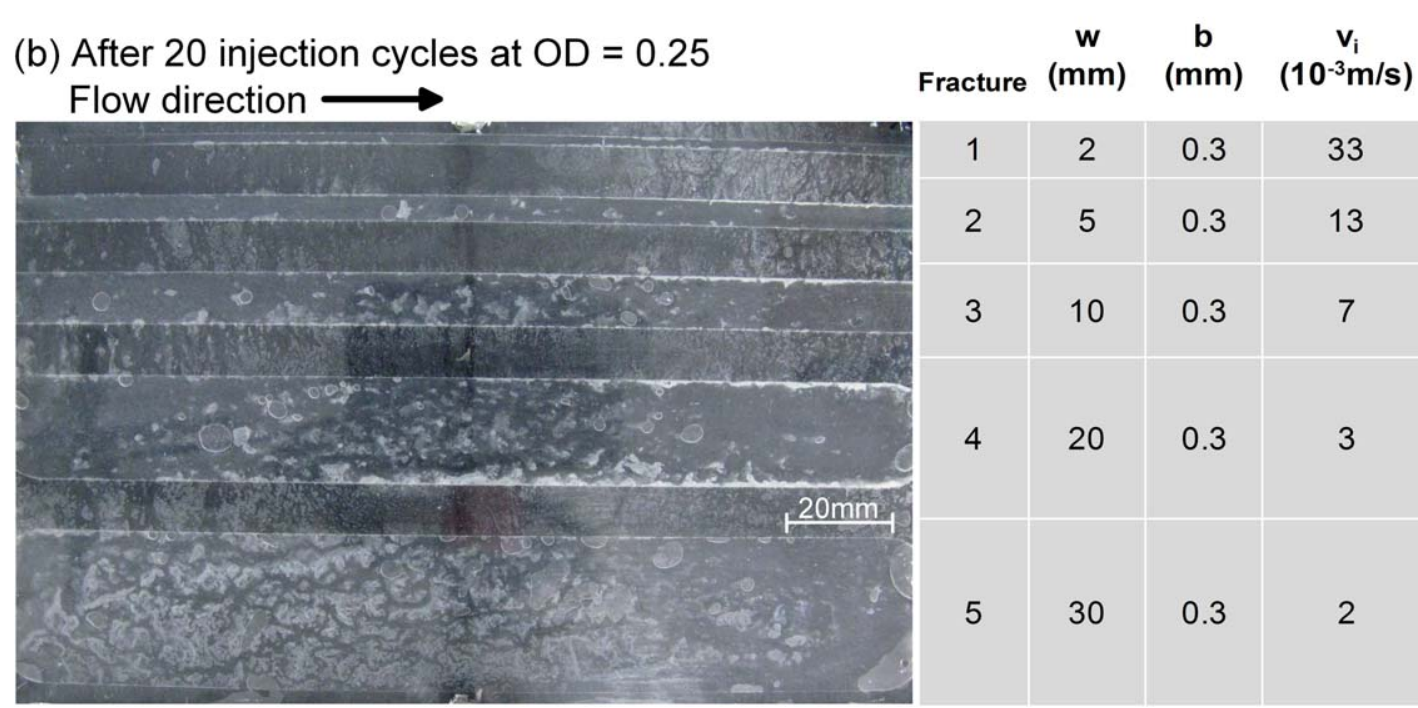

\begin{tabular}{|l|l|l|l|}
\hline 1 & 2 & 0.3 & 33 \\
\hline 2 & 5 & 0.3 & 13 \\
\hline 3 & 10 & 0.3 & 7 \\
\hline 4 & 20 & 0.3 & 3 \\
\hline 5 & 30 & 0.3 & 2 \\
\hline
\end{tabular}

Figure 6. Influence of bacterial density on calcite precipitation at $\mathrm{Q}=1.2 \mathrm{~mL} / \mathrm{min}$ (Flow Cell 2): (a) after five injection cycles at $1.0 \mathrm{OD}_{600}$ and (b) after 20 injection cycles at $0.25 \mathrm{OD}_{600}$. W is the width of an individual fracture perpendicular to the flow direction and marked in Figures $4 \mathrm{a}$ and $4 \mathrm{~b}$ is the fracture aperture and $\mathrm{v}$ is the initial average fracture velocity, i.e., prior to precipitation.

fracture widths (Figure 1d). Figure 6a presents Flow Cell 2 after five injection cycles had been carried out at a flow rate of $1.2 \mathrm{~mL} / \mathrm{min}$ with an $\mathrm{OD}_{600}=1.0$. The pattern of precipitation observed in Figure 6a is strikingly similar in all of the five fractures, with channeling being more developed in the fractures with lower (initial) velocities. Figure $6 \mathrm{~b}$ presents Flow Cell 2 after 20 injection cycles have been carried out at an $\mathrm{OD}_{600}=0.25$. As the bacterial density $\left(\mathrm{OD}_{600}\right)$ was reduced from 1.0 to $0.25 \mathrm{OD}_{600}$, the diameter of the largest flocs in the suspension decreased. By comparing Figures $6 \mathrm{a}$ and $6 \mathrm{~b}$ it is apparent that after 4 times as many injection cycles, the mass of precipitates still remained less in the fractures with the lower $\mathrm{OD}_{600}$. Furthermore, in Figure 6b, where the experiment was conducted using the lower optical density $\left(0.25 \mathrm{OD}_{600}\right)$, the formation of tortuous flow paths is only apparent in Fracture 5. In the other fractures in Figure 6b, the precipitation appeared to be more patch like, i.e., at an earlier stage of channel development. The evidence for lower settling velocities, due to a reduction in the diameter of the largest flocs present in the $0.25 \mathrm{OD}_{600}$ suspension, is most apparent in Fractures 2, 3, and 4 of Figure 6b, where the flocs have evidently been transported further along the fracture before settling out (i.e., precipitation is further downstream compared to that in Figure 6a).

[30] For both Figures $6 \mathrm{a}$ and $6 \mathrm{~b}$, the experiments were carried out using approximately the same total numbers of bacteria and equal injection volumes per cycle (see Table 2) resulting in the same total availability of calcium ions and urea in each fracture. The experiment confirms the proposition that larger floc sizes give rise to higher settling velocities, which resulted in increased precipitation near the inlet as well as increased total mass of precipitate on the fracture surfaces. 


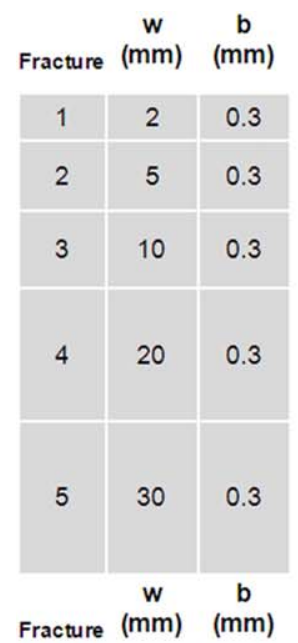

(a) After 24 injection cycles at $Q=1.2 \mathrm{ml} / \mathrm{min}$ Flow direction $\longrightarrow$

(d)
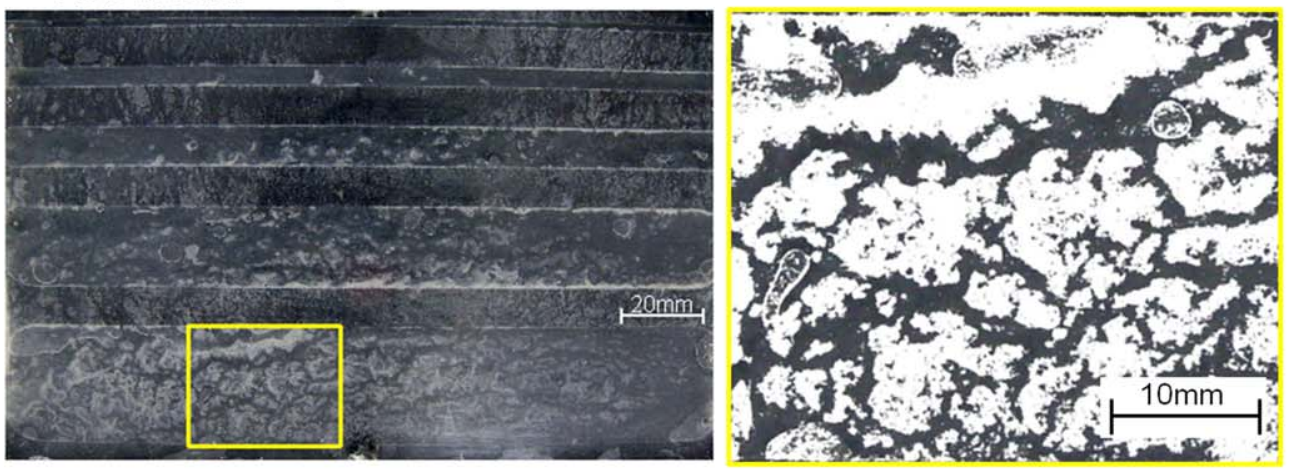

(b) After 25 injection cycles at $Q=1.2 \mathrm{ml} / \mathrm{min}$ Flow direction

(e)

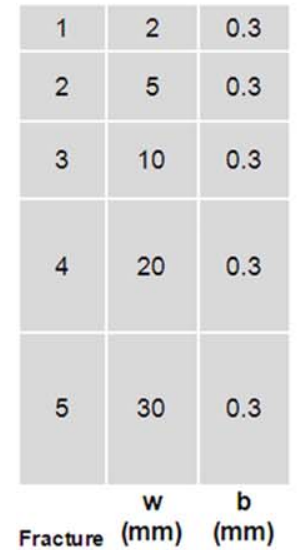

Fracture $(\mathrm{mm})(\mathrm{mm})$

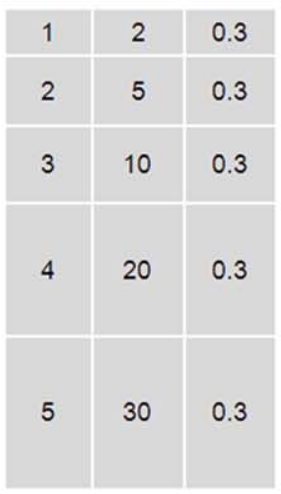

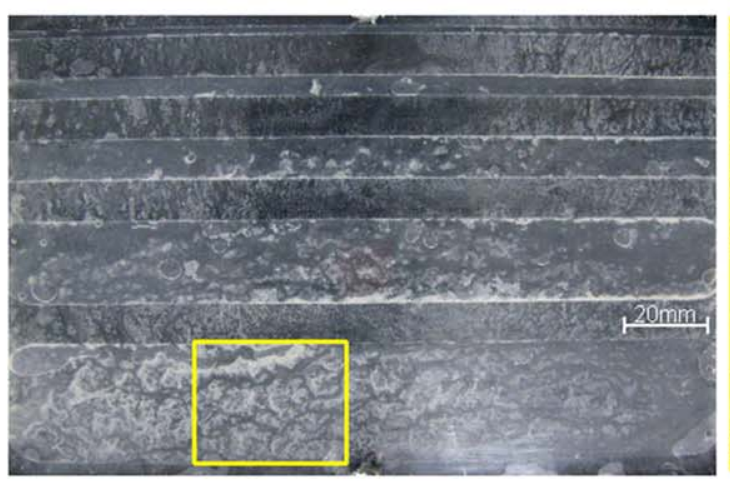

(c) After 10 additional cycles at $Q=0.6 \mathrm{ml} / \mathrm{min}$

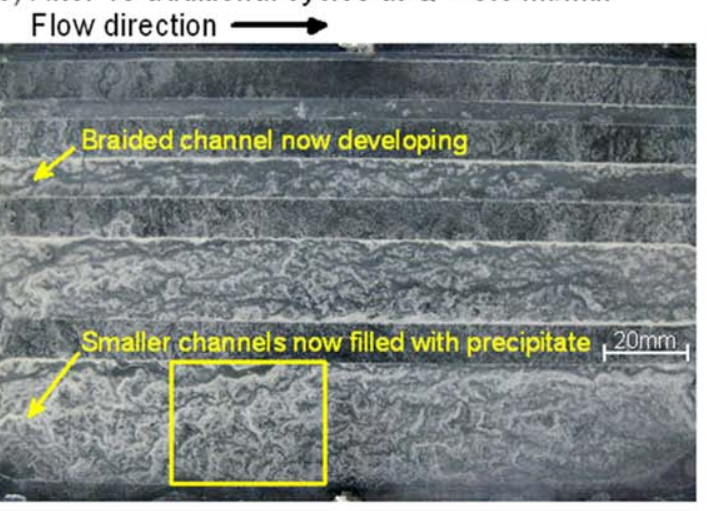

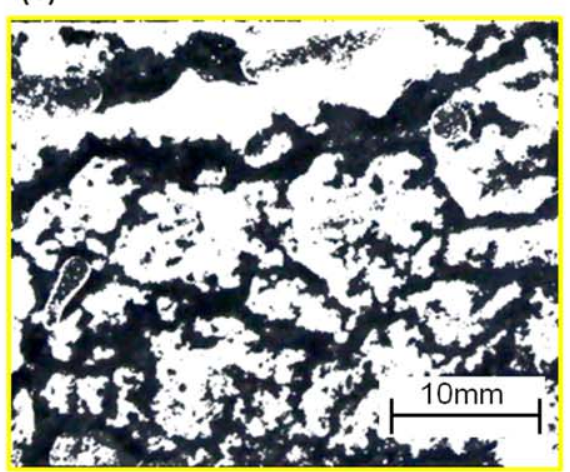

(f)

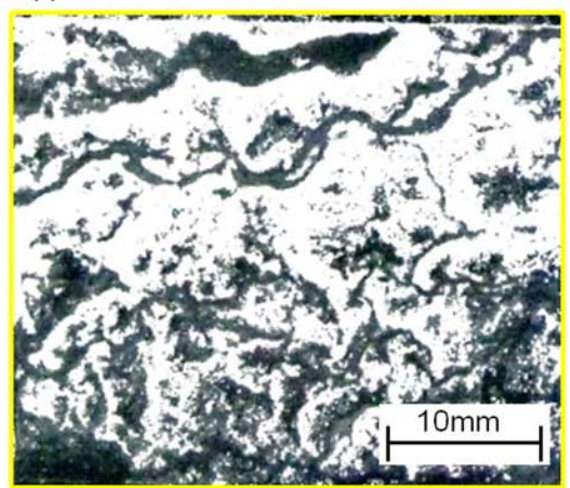

Figure 7. Influence of flow rate on calcite precipitation at an $\mathrm{OD}_{600}$ of 0.25 (Flow Cell 2): (a) after 24 injection cycles at $\mathrm{Q}=1.2 \mathrm{~mL} / \mathrm{min}$, (b) after 25 injection cycles at $\mathrm{Q}=1.2 \mathrm{~mL} / \mathrm{min}$, (c) After an additional 10 injection cycles at $\mathrm{Q}=0.6 \mathrm{~mL} / \mathrm{min},(\mathrm{d}-\mathrm{f})$ digital estimations of the channel patterns formed within the rectangle marked in Figures $7 \mathrm{a}-7 \mathrm{c}$, respectively, which have been determined using the thresholding technique using Image J. W is the width of an individual fracture perpendicular to the flow direction and marked in Figures $4 \mathrm{a}$ and $4 \mathrm{~b}$ is the fracture aperture.

\subsection{Reducing the Flow Rate}

[31] Our experiments have indicated that the mass and spatial distribution of microbially induced calcite precipitates on the lower fracture surface are principally controlled by the ratio of shear velocity at fracture surfaces to floc settling velocity. This implies that, by dropping the flow rate within a fracture, it should be possible to fill previously stable open channels. To test this hypothesis, we ran Flow
Cell 2 for 25 injection cycles at an initial flow rate of $\mathrm{Q}=1.2 \mathrm{~mL} / \mathrm{min}$. A comparison of the precipitate at 24 and 25 cycles (Figures $7 \mathrm{a}$ and $7 \mathrm{~d}$ and Figures $7 \mathrm{~b}$ and $7 \mathrm{e}$, respectively) shows that, whilst some precipitation was occurring within the mass of precipitates, the open channels themselves had become stable (Figures 7a, 7b, 7d, and 7e, Experiment $4 \mathrm{a}$ in Table 2). The flow rate was then halved to $0.6 \mathrm{~mL} / \mathrm{min}$ and an additional 10 injection cycles were carried out (see Figure 7c). By dropping the flow rate, 

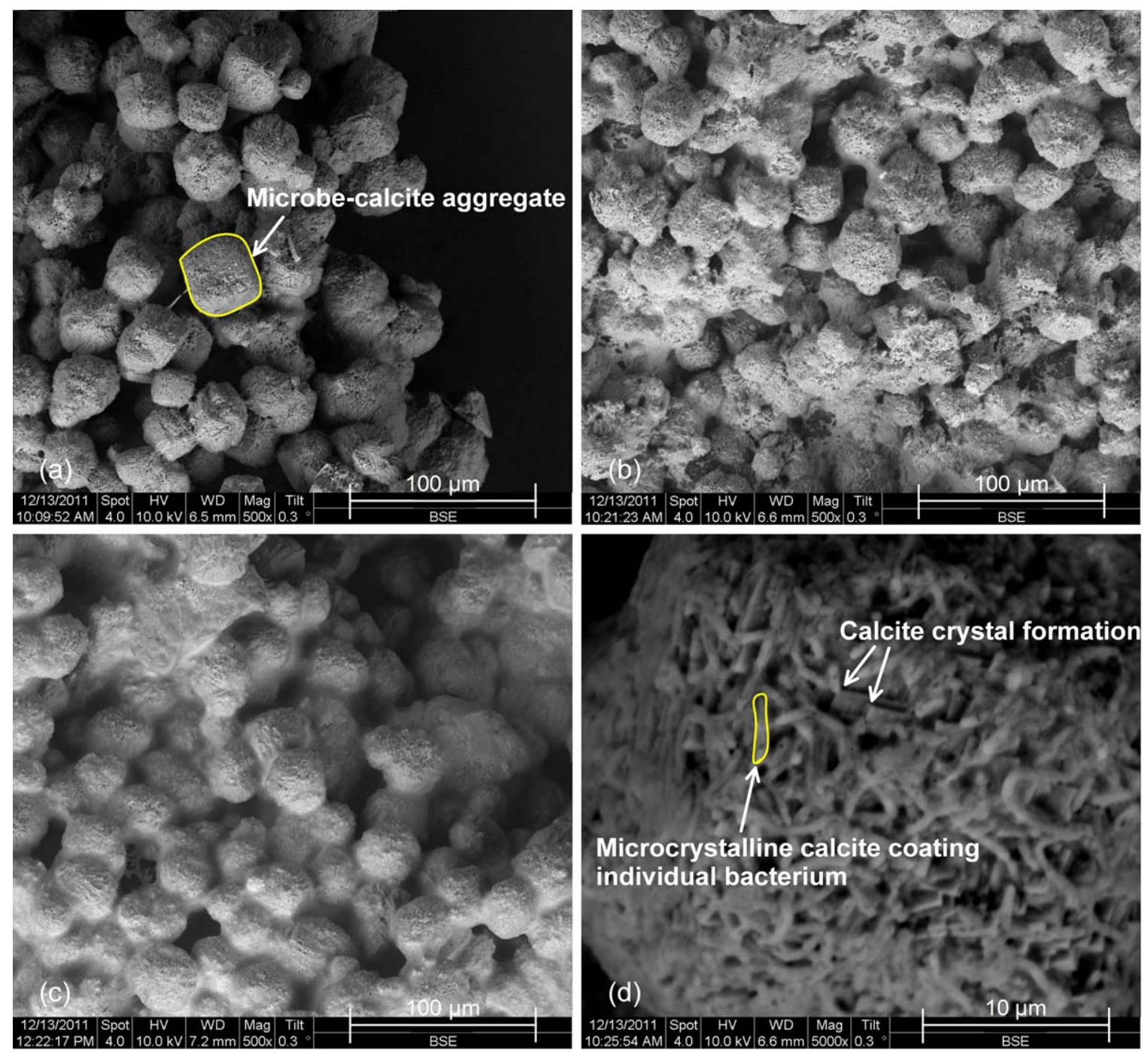

Figure 8. Back scattered electron images of calcite precipitated under continuous flow conditions (Flow cell 2, Q = $1.2 \mathrm{~mL} / \mathrm{min}$ ): (a) calcite sampled at location A, (sampled proximal to an open channel), (b) calcite sampled at location B (sampled from a position set-back from open channel), (c) calcite sampled at location $\mathrm{C}$ (sampled from position located far from open channel), and (d) a single microbecalcite aggregate sampled at location $\mathrm{B}$, at higher magnification. Locations $\mathrm{A}, \mathrm{B}$, and $\mathrm{C}$ are marked on Figure 6a.

Figure 7c illustrates that as predicted, some of the previously open channels within the fracture started to in-fill, which reduced the width of the remaining open channels (compare Figures 7e and 7f) while other channels became completely blocked with calcite (see Fracture 5, Figure 7c). This supports the hypothesis that it is the local velocity variations that predominantly control the eventual spatial distribution of microbially induced calcite precipitates on the fracture surfaces, with precipitation forming on cell surfaces, while microbes are still in suspension and/or after deposition.

\subsection{Microbially Induced Calcite Morphology}

[32] To investigate the morphology of the calcite under different flow conditions within the channel network, specimens were sampled for examination using Scanning Electron Microscopy (SEM) from 12 different locations.
Locations were classified into three distinct types, since they correlated to consistently different calcite morphology; proximal to an open channel (where the velocities are higher), set back slightly from an open channel and far from an open channel. SEM images of representative samples from each of the three location types (proximal, set-back, and far-samples A, B, and C, respectively) are shown in Figure 8 and their locations are marked on Figure $6 \mathrm{a}$.

[33] There is a noticeable difference between the SEM images of Specimens A, B, and C: as we move to locations at a greater distance from the main open channel, there are more bridges and linkages between the microbe-calcite aggregates. This is particularly evident in Figure 8c where many of the aggregates appear to be linking together to form a calcite matrix. This suggests that in locations with higher channel velocities, such as Location A close to the main remaining open channel, calcite growth was limited, 
whereas in the areas of lower channel velocities (Location C) additional crystal growth occurred (compared to A), in the form of bridges between microbe-calcite aggregates These observations were consistent for all specimens from the three different locations analyzed under the SEM.

[34] Figure 8d shows a single microbe-calcite aggregate from Location $B$, at higher magnification. It is evident that calcite has precipitated on the surface of the bacteria, and that calcite encrusted bacteria are rod like and several microns in length. This supports the theory that calcite precipitates nucleate on the surface of the bacterium [e.g., Schultze-Lam et al., 1996; Stocks-Fischer et al., 1999]. Distinct crystal growth in the form of calcite plates (the beginning of rhombohedrons) are also visible in Figure $8 \mathrm{~d}$ among the mass of calcite coated bacteria. The microbecalcite aggregates appear to be highly uniform in size, around $30-40 \mu \mathrm{m}$. This morphology is distinctly different from the SEM images of predominantly rhombohedral calcite crystals reported by other researchers [e.g., Tobler et al., 2012], where experiments include periods of no flow.

\section{Discussion}

[35] For microbially induced calcite precipitation, we have shown that fluid velocity is a key control on the pattern of precipitates observed on the fracture surfaces. Our experiments have shown that as calcite precipitates, the fracture aperture distribution is altered and spatially variable patterns of velocity develop which in turn result in increased mass of precipitate in regions of low flow velocities. This greater mass of precipitates acts to reduce the fracture aperture in those locations, further reinforcing the existence of the channel network. This feedback mechanism between velocity and microbially mediated precipitation, ultimately leads to the maintenance of a small number of self-organized channels that remain open within the fracture fill.

[36] Many processes contribute to nucleation and growth of microbially mediated mineral precipitation within fractures. Evidence from the SEM images confirms that in these experiments calcite appears to be predominantly nucleated on the surface of the bacteria. The importance of the bacteria cells as nucleation surfaces is clear if we compare available fracture surface area to cell surface area within one experiment, for example: considering Fracture 8 (the widest fracture) in Flow Cell 1 has a surface area of $7240 \mathrm{~mm}^{2}$, assuming perfectly smooth surfaces. The microbial suspension, with an $\mathrm{OD}_{600}=1.0$ corresponds approximately to $3 \times 10^{8}$ colony-forming unit $(\mathrm{CFU}) / \mathrm{mL}$ (using the relationship determined for $S$. pasteurii by [Parks, 2009]). In Experiment 1 (Table 2) a total of 168 $\mathrm{mL}$ of microbial suspension was injected into Fracture 8 (five injections of $33.6 \mathrm{~mL}$ ), therefore potentially $5 \times 10^{10}$ cells could have acted as nucleation surfaces. Assuming $S$. pasteurii have a diameter of $0.5 \mu \mathrm{m}$ and a length of $2.5 \mu \mathrm{m}$ (values selected by visual observation of SEM images) this corresponds to a total cell surface area of approximately $216,000 \mathrm{~mm}^{2}$. Hence, the bacteria clearly provide a much greater surface area for potential nucleation than the fracture surfaces.

[37] Nucleation and growth of calcite occurs while the microbial cells or flocs are still in suspension (and/or after they have been deposited on the lower fracture surface).
Our experiments indicate that sedimentation processes dominate the transport of the resulting microbial aggregates (and flocs) within the fractures, with the overwhelming majority of the calcite precipitates located on the lower fracture surface due to gravitational settling of microbecalcite aggregates. We have demonstrated that the rate at which the aggregates settle is controlled by the diameter of the aggregate. Feedback occurs because once aggregates have settled on the initially smooth fracture surface; they act as obstacles to advective flow resulting in regions of low velocity immediately downstream. These low velocity regions promote increased calcite precipitation and crystal growth, and as more and more aggregates settle out of suspension, preferential channels are formed within the fracture. Once the shear velocity at the fracture surfaces exceeds the settling velocity of an individual aggregate, aggregate deposition is inhibited and any deposited aggregates will become mobilized [Van Rijn, 1984]. The shear velocity required to keep aggregates in suspension, and hence channels open, will drop with decreasing aggregate size. High fracture velocities were investigated in these experiments, but in natural groundwaters where the concentration of microbes is lower and thus the size of flocs is likely to be much smaller, lower channel velocities would be required to inhibit deposition and thus to maintain channels open.

[38] Individual bacteria cells are transported to all fracture surfaces by Brownian diffusion [Yao et al., 1971]. Their attachment is known to be dependent on the sum of the electrostatic forces acting between the bacterial cell and the surface, including electrical double-layer repulsion (or attraction) and van der Waals forces [DeNovio et al., 2004; Bradford et al., 2006]. Heterogeneous nucleation of calcite on individual cells may be one of the mechanisms contributing to the thin layer of fine calcite observed on all fracture surfaces. It could, however, also be as a result of heterogeneous nucleation of calcite on the fracture surfaces themselves. Once nucleation has occurred then calcite growth is enhanced at the fracture walls and particularly within the corners of the fractures, as these are low velocity regions, and have correspondingly low shear rates. This results in a very thin layer of calcite precipitating on all the fracture surfaces, alongside slightly greater precipitation in the channel corners. These fine precipitates were observed in our experiments during the early injection cycles and whitening of these fine precipitates did not appear to progress during the experiment. This is consistent with the observations of Holmqvist et al., [2005], who demonstrated that low shear rates (low flow velocities) enhance crystallization by improving transport to crystal surfaces whereas higher shear rates (higher flow velocities) considerably reduce growth rates and ultimately prevent crystal growth, due to particles being sheared off from the crystal surface and by preventing incorporation of particles in the fluid phase into the crystal structure.

[39] Throughout all the artificial fracture experiments conducted, it was repeatedly observed that less calcite precipitation occurred during the first injection cycle than in subsequent cycles. One potential explanation for this is the initially pristine condition of the smooth-walled fracture, which may affect the sedimentation process. Once calcite precipitation is initialized, increased surface roughness 


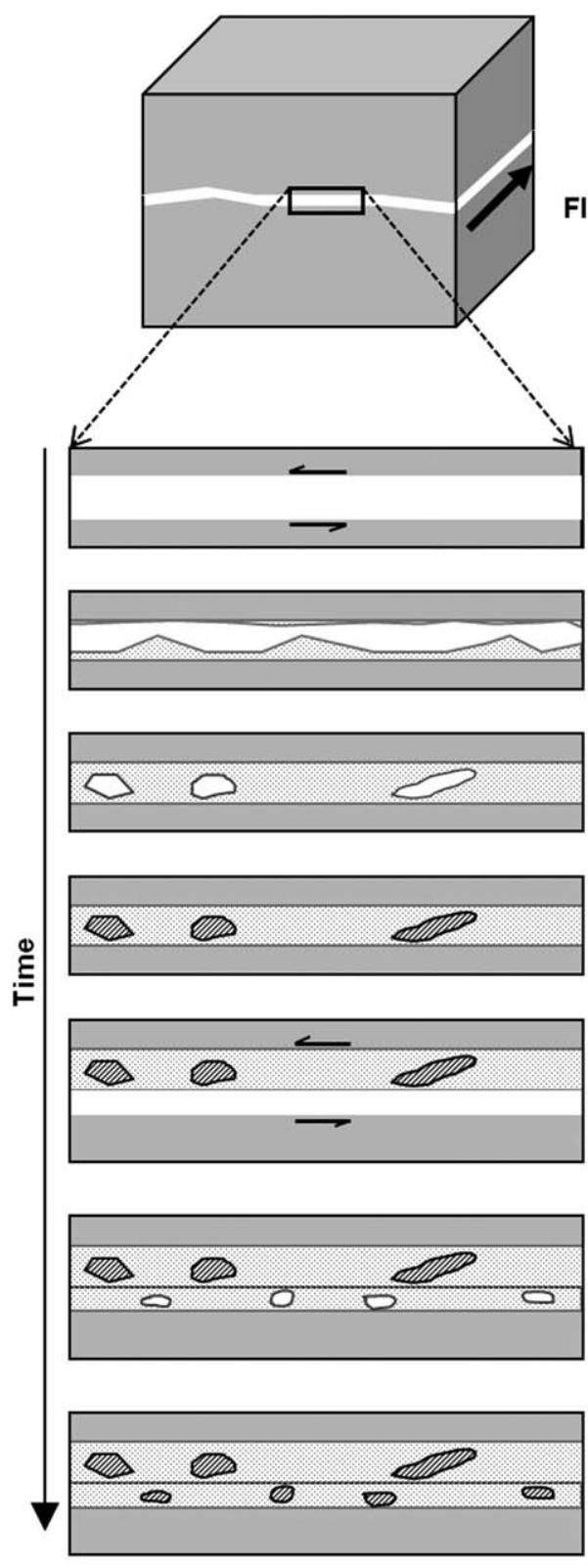

Flow direction

Open fracture created

Conditions suitable for microbially mediated mineral precipitation

Flow driver is maintained-sparse stable channels are formed due to the velocity feedback mechanism

Fracture seals either due to a reduction in flow rate or an alternative mineralization process

Fracture reactivation due to either tectonic or pressure-induced changes in effective stress

The whole process repeats in a cyclic fashion...

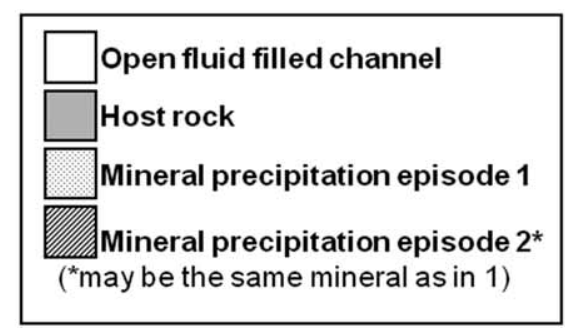

Figure 9. Possible development of complex patterns of microbially mediated fracture mineralization over geological time scales.

enhances the boundary layer effect, increasing drag near the surface and reducing the advective velocity. This will promote floc settling. In addition, the activation energy required for nucleation is typically greater than for crystal growth [e.g., Rodriguez-Blanco et al., 2011], thus growth proceeds more rapidly once calcium carbonate nuclei have already formed in the system. There may also be an influence of the negative surface charge on the pristine polycarbonate sheet, which may repel to some extent the deposition of individual bacteria and flocs and reduce attachment due to electrostatic forces. This is consistent with the results of Schultz et al. [2011] and Tobler et al. [2012] who also noted that calcite precipitation increases once calcite is present on a material surface.
[40] An observation in the experiments carried out with the $1.0 \mathrm{OD}_{600}$ microbial suspension (characterized by a higher $\mathrm{d}_{90}$ floc size), was that the mass of precipitation was always greater closest to the injection point and decreased along the length of the fracture. Several mechanisms combine to promote this. First, the larger floc sizes result in more rapid sedimentation, closer to the inlet. Second, once flocs have settled and calcite has precipitated, the fracture aperture is reduced resulting in a straining of the flocs and individual microbes. Finally, whilst early in the precipitation process straining occurs, once stable narrow channels have been formed the increased channel velocity was observed to exert sufficient force to break down the large flocs and further straining was inhibited. Immobilization of 
particles closer to the inlet is predicted in classical filtration theory (CFT) models [e.g., Yao et al., 1971]. However, more recently experimental studies [Tufenkji and Elimelech, 2004; Gargiulo et al., 2007] have demonstrated that microbial filtration is significantly greater closer to the inlet than that predicted by CFT due to the more complex nature of microbe-surface interactions. In addition, the greater mass of precipitates located closer to the injection point may also be due to depletion of the reactants' concentrations further downstream, as observed by Hilgers and Urai [2002]. However, this is thought to occur only when flow velocities are sufficiently small [Nollet et al., 2006] and thus is unlikely to be the main reason for the variation observed with length along the fractures in this study.

[41] There is considerable field evidence for the formation of isolated, open channels within mineral-filled fractures. In hydrogeology, it is now a well-accepted view that flow in fractured rock is predominantly focused through channels, which cover an (often small) proportion of the total fracture surface [e.g., Abelin et al., 1985; Bourke, 1987; Neretnieks, 1985; Durham, 1997]. Factors contributing to this channeling have been studied from theoretical, numerical, and experimental perspectives, including initial aperture distribution [e.g., Moreno et al., 1985; Tsang and Tsang, 1987; Brown et al., 1998] and relative permeability in multiphase systems [e.g., Birkholzer and Tsang, 1997; Glass et al., 2002; Chen et al., 2004]. Channeling due to (chemical) dissolution and or precipitation of minerals has also been widely investigated [e.g., Durham et al., 2001; Andre and Rajaram, 2005; Detwiler, 2010].

[42] Pedersen et al. [1997] present field observations in which there is strong evidence for microbially mediated calcite precipitation at depth based on stable isotope analyses; they comment that different generations of calcite were not precipitated uniformly across the entire fracture surface but rather they observed a channel-like pattern. Budai et al. [2002] who linked calcite precipitation in fractures with microbial methane generation and oxidation, presented photographic evidence of calcite located in irregular patches and of channelized calcite precipitation on fracture surfaces at the Norwood outcrop. These natural channels are on a millimeter scale with a similar size and distribution to those in our experiments. Such field observations of channeling within fractures could be explained by the hydrodynamic feedback mechanism between fluid velocity and microbially mediated mineral precipitation demonstrated by our experiments.

[43] For hydrodynamic feedback to result in open channels remaining stable over a given time period, there must be a regional driver for groundwater flow otherwise the channels will begin to block in periods of low flow. Examples might include regional (deep) circulation of meteoric/ glacial melt waters or hydrothermal fluids. Over geological times scales this could conceivably lead to a cyclic process (Figure 9) of: fracture creation; possible microbially mediated precipitation leading to stable channel formation (during a period in which groundwater flow is maintained); channel sealing, either by the same microbially mediated precipitation process with decreased groundwater flow rates, or by an alternative mineralization process; subsequent pressure induced or tectonic fracture reactivation leading to fracture reopening; then continued mineralization. We postulate that this could result in complex patterns of fracture mineralization such as those illustrated in Figure 9. It should be noted that shallow meteoric groundwater circulation would not tend to result in similar patterns of mineralization and channel formation, since as the channels block there is no mechanism for pressure-induced reactivation.

\section{Conclusions}

[44] The experimental results presented in this paper have shown that under flowing conditions, the spatial distribution of microbially induced calcite precipitates on fracture surfaces is controlled by fluid velocity. The main conclusions of the paper are:

[45] 1. Even for a uniform initial fracture aperture with a steady flow rate, a feedback mechanism exists between velocity and precipitation that results in mineral-fill distributions that focus flow into a small number of selforganizing channels that remain stable. Ultimately, this feedback mechanism controls the final aperture profile governing flow within the fracture.

[46] 2. Our experiments demonstrate that calcite precipitates nucleate on bacteria cell surfaces and that the transport of flocculated bacteria to fracture surfaces is governed by sedimentation. The microbial flocs settle out of a quiescent solution at a velocity that is dependent on individual floc size and density. This settling velocity competes with the shear velocity, inhibiting deposition via entrainment. As precipitation progresses, the flow becomes more channeled within the fracture, enhancing precipitation in regions of low flow and inhibiting it in the remaining high velocity channels.

[47] 3. Our results could explain field observations of microbially mediated calcite precipitation at depth [Pedersen et al., 1997; Budai et al., 2002] where evidence of channelized mineral fill, on similar scales, has been observed in natural fractures.

[48] Acknowledgments. This work was funded by the Engineering and Physical Sciences Research Council (EPSRC) grant (EP/G063699/1).

\section{References}

Abelin, H., I. Neretnieks, S. Tunbrant, and L. Moreno (1985), Final report of the migration in a single fracture-Experimental results and evaluation, Tech. Rep. 85-55, Royal Inst. Technol., Stockholm, Sweden.

Andre, B. J., and H. Rajaram (2005), Dissolution of limestone fractures by cooling waters: Early development of hypogene karst systems, Water Resour. Res., 41, W01015, doi:10.1029/2004WR003331.

Bang, S. S., J. K. Galinat, and V. Ramakrishnan (2001), Calcite precipitation induced by polyurethane-immobilized Bacillus pasteurii, Enzyme Microb. Technol., 28, 404-409.

Beveridge, T. J., and R. J. Doyle (1989), Metal Ions and Bacteria, 461 pp., Wiley-Interscience., New York.

Birkholzer, J., and C.-F. Tsang (1997), Solute channeling in unsaturated heterogeneous porous media, Water Resour. Res., 33(10), 2221-2238.

Bourke, P. J. (1987), Channeling of flow through fractures in rock, in Proceedings of GEOVAL-87, pp. 167-177, Swedish Nucl. Power Insp., Stockholm, Sweden.

Bradford, S. A., J. Simunek, M. Bettahar, M. T. van Genuchten, and S. R. Yates (2006), Significance of straining in colloid deposition: Evidence and implications, Water Resour. Res., 42, W12S15, doi:10.1029/ 2005WR004791.

Brown, D. A., D. C. Kamineni, J. A. Sawicki, and T. J. Beveridge (1994), Minerals associated with biofilms occurring on exposed rock in a granitic underground research laboratory, Appl. Environ. Microbiol. 60(9), 31823191 . 
Brown, S. R., A. Ciprihan, and R. Hardy (1998), Experimental observations of fluid flow channels in a single fracture, J. Geophys. Res., 103(B3), 5125-5132.

Budai, J. M., A. M. Martini, L. M. Walter, and T. C. W. Ku (2002), Fracture-fill calcite as a record of microbial methanogenesis and fluid migration: A case study from the Devonian Antrim Shale, Michigan Basin, Geofluids, 2, 163-183.

Chen, C.-Y., R. N. Horne, and M. Fourar (2004), Experimental study of liquid-gas flow structure effects on relative permeabilities in a fracture, Water Resour. Res., 40, W08301, doi:10.1029/2004WR003026.

Cheong, W. C., P. H. Gaskell, and A. Neville (2013), Substrate effect on surface adhesion/crystallisation of calcium carbonate, J. Cryst. Growth, $363,7-21$.

Cunningham, A. B., R. Gerlach, L. Spangler, and A. C. Mitchell (2009), Microbially enhanced geologic containment of sequestered supercritical $\mathrm{CO}_{2}$, Energy Procedia, 1(1), 3245-3252, doi:10.1016/j.egypro.2009.02.109.

Cuthbert, M. O., M. S. Riley, S. Handley-Sidhu, J. C. Renshaw, D. J. Tobler, V. R. Phoenix, and R. Mackay (2012), Controls on the rate of ureolysis and the morphology of carbonate precipitated by $S$. Pasteuri biofilms and limits due to bacterial encapsulation, Ecol. Eng., 41, 32-40, doi:10.1016/j.ecoleng.2012.01.008.

Cuthbert, M. O., L. A. McMillan, S. Handley-Sidhu, M. S. Riley, D. J. Tobler, and V. R. Phoenix (2013), A field and modeling study of fractured rock permeability reduction using microbially induced calcite precipitation, Environ. Sci. Technol., 47(23), 13637-13643, doi:10.1021/ es402601g.

De Muynck, W., N. De Beliea, and W. Verstraeteb (2010), Microbial carbonate precipitation in construction materials: A review, Ecol. Eng., 36, 118-136, doi:10.1016/j.ecoleng.2009.02.006.

De Schryver, P., R. Crab, T. Defoirdt, N. Boon, and W. Verstraete (2008), The basics of bio-flocs technology: The added value for aquaculture, Aquaculture, 277, 125-137.

DeJong, J. T., M. B. Fritzges, and K. Nüsslein (2006), Microbially induced cementation to control sand response to undrained shear, J. Geotech Geoenviron. Eng., 132(11), 1381-1392, doi:10.1061/(ASCE)10900241(2006)132:11(1381).

DeNovio, N. M., J. E. Saiers, and J. N. Ryan (2004), Colloid movement in unsaturated porous media: Recent advances and future directions, Vadose Zone J., 3, 338-351, doi:10.2113/3.2.338.

Derjaguin, B. V., and L. Landau (1941), Theory of the stability of strongly charged lyophobic sols and the adhesion of strongly charged particles in solutions of electrolyte, Acta Physicochim., 14, 633-662.

Detwiler, R. L. (2010), Permeability alteration due to mineral dissolution in partially saturated fractures, J. Geophys. Res., 115, B09210, doi: 10.1029/2009JB007206.

Droppo, I. G. (2004), Structural controls on floc strength and transport, Can. J. Civ. Eng., 31, 569-578, doi:10.1139/L04-015.

Droppo, I. G., N. Ross, M. Skafel, and S. N. Liss (2007), Biostabilization of cohesive sediment beds in a freshwater wave-dominated environment, Limnol. Oceanogr., 52(2), 577-589.

Durham, W. B. (1997), Laboratory observations of the hydraulic behaviour of a permeable fracture from $3800 \mathrm{~m}$ depth in the KTB pilot hole, J. Geophys. Res., 102(B8), 18,405-18,416.

Durham, W. B., W. L. Bourcier, and E. A. Burton (2001), Direct observation of reactive flow in a single fracture, Water Resour. Res., 37(1), 1-12, doi:10.1029/2000WR900228.

Ferris, F. G., and L. G. Stehmeier (1992), Bacteriogenic mineral plugging, Patent $[5,143,155]$, U.S. Pat. Off., Washington, D. C.

Ferris, F. G., L. G. Stehmeier, A. Kantzas, and F. M. Mourits (1996), Bacteriogenic mineral plugging, J. Can. Pet. Technol., 35(8), 56-61, doi: 10.2118/96-08-06.

Ferris, F. G., V. Phoenix, Y. Fujita, and R. Smith (2003), Kinetics of calcite precipitation induced by ureolytic bacteria at 10 to $20^{\circ} \mathrm{C}$ in artificial groundwater, Geochim. Cosmochim. Acta, 67(8), 1701-1710, doi: 10.1016/S0016-7037(00)00503-9.

Fridrich, C. J., W. W. Dudley Jr., and J. S. Stuckless (1994), Hydrogeologic analysis of the saturated-zone ground-water system, under Yucca Mountain, Nevada, J. Hydrol., 154(1-4), 133-168, doi:10.1016/00221694(94)90215-1.

Fujita, Y., J. L. Taylor, T. L. T. Gresham, M. E. Delwiche, F. S. Colwell, T. L. McLing, L. M. Petzke, and R. W. Smith (2008), Stimulation of microbial urea hydrolysis in groundwater to enhance calcite precipitation, Environ. Sci. Technol., 42(8), 3025-3032, doi:10.1021/es702643g.
Gadd, G. M. (2010), Metals, minerals and microbes: Geomicrobiology and bioremediation, Microbiology, 156, 609-643, doi:10.1099/ mic.0.037143-0.

Gargiulo, G., S. Bradford, J. Simůnek, P. Ustohal, H. Vereecken, and E. Klumpp (2007), Bacteria transport and deposition under unsaturated conditions: The role of the matrix grain size and the bacteria surface protein, J. Contam. Hydrol., 92(3-4):255-273.

Gil'man, A. B., A. I. Drachev, L. E. Vengerskaya, G. K. Semenova, A. A. Kuznetsov, and V. K. Potapov (2003), Charging of polycarbonate films in a direct-current discharge, High Energy Chem., 37(4), 267-271.

Gollapudi, U. K., C. L. Knutson, S. S. Bang, and M. R. Islam (1995), A new method for controlling leaching through permeable channels, Chemosphere, 30(4), 695-705.

Glass, R. J., M. J. Nicholl, S. E. Pringle, and T. R. Wood (2002), Unsaturated flow through a fracture-matrix network: Dynamic preferential pathways in mesoscale laboratory experiments, Water Resour. Res., 38(12), 17-1-17-7, doi:10.1029/2001WR001002.

Hammes, F., and W. Verstraete (2002), Key roles of pH and calcium metabolism in microbial carbonate precipitation, Rev. Environ. Sci. Biotechnol., 1, 3-7.

Harkes, M. P., L. A. van Paassen, J. L. Booster, V. S. Whiffin, and M. C. M. van Loosdrecht (2010), Fixation and distribution of bacterial activity in sand to induce carbonate precipitation for ground reinforcement, Ecol. Eng., 36(2), 112-117, doi:10.1016/j.ecoleng.2009.01.004.

Heath, M. J. (1985), Geological control of fracture permeability in Carnmenellis granite, Cornwall: Implications for radionuclide migration, Mineral. Mag., 49, 233-244.

Heim, C., et al. (2012), Ancient microbial activity recorded in fracture fillings from granitic rocks (Äspo Hard Rock Laboratory, Sweden), Geobiology, 10, 280-297, doi:10.1111/j.1472-4669.2012.00328.x.

Higgins, M. J., and J. T. Novak (1997), Characterization of exocellular protein and its role in bioflocculation, J. Environ. Eng., 123(5), 479-485.

Hilgers, C., and J. L. Urai (2002), Experimental study of syntaxial vein growth during lateral flow in transmitted light: First results, J. Struct. Geol., 24, 1029-1043.

Hogg, S. (2013), Essential Microbiology, 2nd ed., 528 pp., John Wiley, Chichester, West Sussex.

Holmqvist, P., M. P. Lettinga, J. Buitenhuis, and J. K. G. Dhont (2005), Crystallization kinetics of colloidal spheres under stationary shear flow, Langmuir, 21, 10,976-10,982, doi:10.1021/la051490h.

Inoue, K., M. Nishimura, B. B. Nayak, and K. Kogure (2007), Separation of marine bacteria according to buoyant density by use of the densitydependent cell sorting method, Appl. Environ. Microbiol., 73(4), 10491053, doi:10.1128/AEM.01158-06.

Johnson, C. P., X.-Y. Li, and B. E. Logan (1996), Settling velocities of fractal aggregates, Environ. Sci. Technol., 30, 1911-1918.

Juniper, S. K., P. Martineu, J. Sarrazin, and Y. Gélinas (1995), Microbialmineral floc associated with nascent hydrothermal activity on CoAxial Segment, Juan de Fuca Ridge, Geophys. Res. Lett., 22(2), 179-182, doi: 10.1029/94GL02436.

Kirby, B. J., and E. F. Hasselbrink Jr. (2004), Zeta potential of microfluidic substrates: 2. Data for polymers, Electrophoresis, 25, 203-213.

Konhauser, K. (2007), Introduction to Geomicrobiology, Blackwell, Oxford.

Leopold, L. B., and M. G. Wolman (1957), River Channel Patterns: Braided, Meandering and Straight, U.S. Geol. Surv. Prof. Pap. 282-B, pp. 39-103.

Li, X.-Y., and Y. Yuan (2002), Settling velocities and permeabilities of microbial aggregates, Water Res., 36, 3110-3120.

Metcalfe, R., M. B. Crawford, A. H. Bath, A. K. Littleboy, P. J. Degnan, and H. J. Richards (2007), Characteristics of deep groundwater flow in a basin marginal setting at Sellafield, Northwest England: ${ }^{36} \mathrm{Cl}$ and halide evidence, Appl. Geochem., 22, 128-151, doi:10.1016/j.apgeochem.2006.09.004.

Mitchell, A. C., and F. G. Ferris (2006), The influence of Bacillus pasteurii on the nucleation and growth of calcium carbonate, Geomicrobiol. J., 23(3-4), 213-226, doi:10.1080/01490450600724233.

Mitchell, A. C., K. Dideriksen, L. H. Spangler, A. B. Cunningham, and R. Gerlach (2010), Microbially enhanced carbon capture and storage by mineral-trapping and solubility-trapping, Environ. Sci. Technol., 44, 5270-5276, doi:10.1021/es903270w.

Moreno, L., I. Neretnieks, and T. Eriksen, (1985), Analysis of some laboratory tracer runs in natural fissures, Water Resour. Res., 21(7), 951-958.

Neretnieks, I. (1985), Transport in fractured rocks, in Proceedings Memoirs of the 17th International Congress of International Association of Hydrologists, vol. 17, pp. 301-318, Int. Assoc. of Hydrol., Tucson, Ariz. 


\section{EL MOUNTASSIR ET AL.: MICROBIALLY MEDIATED MINERALIZATION}

Nollet, S., C. Hilgers, and J. L. Urai (2006), Experimental study of polycrystal growth from an advecting supersaturated fluid in a model fracture, Geofluids, 6, 185-200, doi:10.1111/j.1468-8123.2006.00142.x.

Nordqvist, R., E. Gustafsson, P. Andersson, and P. Thur (2008), Groundwater flow and hydraulic gradients in fractures and fracture zones at Forsmark and Oskarshamn, SKB Tech. Rep. R-08-103, 69 pp., Stockholm.

Parks, S. L. (2009), Kinetics of calcite precipitation by ureolytic bacteria under aerobic and anaerobic conditions, MSc thesis, Mont. State Univ., Bozeman.

Pedersen, K. (1997), Microbial life in deep granitic rock, FEMS Microbiol. Rev., 20, 399-414.

Pedersen, K., J. Arlinger, S. Ekendahl, and L. Hallbeck (1996), 16S rRNA gene diversity of attached and unattached groundwater bacteria along the access tunnel to the Äspö Hard Rock Laboratory, Sweden, FEMS Microbiol. Ecol., 19, 249-262.

Pedersen, K., S. Ekendahl, E.-L. Tullborg, H. Furnes, I.-G. Thorseth, and O. Tumyr (1997), Evidence of ancient life at $207 \mathrm{~m}$ depth in a granitic aquifer, Geology, 25, 827-830.

Phillips, A. J., E. Lauchnor, J. Eldring, R. Esposito, A. C. Mitchell, R. Gerlach, A. B. Cunningham, and L. H. Spangler (2013), Potential $\mathrm{CO}_{2}$ leakage reduction through biofilm-induced calcium carbonate precipitation, Environ. Sci. Technol., 47, 142-149, doi:10.1021/es301294q.

Rodriguez-Blanco, J. D., S. Shaw, and L. G. Benning (2011), The kinetics and mechanisms of amorphous calcium carbonate (ACC) crystallization to calcite, via vaterite, Nanoscale, 3, 265-271, doi:10.1039/c0nr00589d.

Rubert, C., P. Ramboz, P. Gautret, T. Dieing, F. Westall, D. Bonijoly, Y. M. Le Nindre, and C. Lerouge, (2009), Spectral and microscopic analyses of fossil microorganisms in a Jurassic oolitic limestone, in Conference on Micro-Raman Spectroscopy and Luminescence Studies, LPI Contrib. 1473, pp. 66-67.

Schultz, L., B. Pitts, A. C. Mitchell, A. B. Cunningham, and R. Gerlach (2011), Imaging biologically induced mineralization in fully hydrated flow systems, Microsc. Today, 19, 12-15, doi:10.1017/S1551929511000848.

Schultze-Lam, S., D. Fortin, B. S. Davis, and T. J. Beveridge (1996), Mineralization of bacterial surfaces, Chem. Geol., 132, 171-181.

Segall, P., and D. D. Pollard (1983), Nucleation and growth of strike slip faults in granite, J. Geophys. Res., 88(B1), 555-568, doi:10.1029/ JB088Ib01P00555.

Stocks-Fischer, S., J. K. Galinat, and S. S. Bang (1999), Microbiological precipitation of $\mathrm{CaCO}_{3}$, Soil Biol. Biochem., 31(11), 1563-1571.

Stoner, D. L., S. M. Watson, R. D. Stedtfeld, P. Meakin, L. K. Griffel, T. L. Tyler, L. M. Pegram, J. M. Barnes, and V. A. Deason (2005), Application of stereolithographic custom models for studying the impact of biofilms and mineral precipitation on fluid flow, Appl. Environ. Microbiol., 71(12), 8721-8728, doi:10.1128/AEM.71.12.8721-8728.2005.

Tobler, D. J., M. O. Cuthbert, R. B. Greswell, M. S. Riley, J. C. Renshaw, S. Handley-Sidhu, and V. R. Phoenix (2011), Comparison of rates of ureolysis between Sporosarcina pasteurii and an indigenous groundwater community under conditions required to precipitate large volumes of calcite, Geochim. Cosmochim. Acta, 75, 3290-3301, doi:10.1016/ j.gca.2011.03.023.

Tobler, D. J., E. MacLachlan, and V. R. Phoenix (2012), Microbially mediated plugging of porous media and the impact of differing injection strategies, Ecol. Eng., 42, 270-278, doi:10.1016/j.ecoleng.2012.02.027.

Trewin, N. H., and A. H. Knoll (1999), Preservation of Devonian chemotrophic filamentous bacteria in calcite veins, Palaios, 14, 288-294.

Tsang, Y. W., and C. F. Tsang (1987), Channel model of flow through fractured media, Water Resour. Res., 23(3), 467-479.

Tufenkji, N., and M. Elimelech (2004), Deviation from the classical colloid filtration theory in the presence of repulsive DLVO interactions, Langmuir, 20, 10,818-10,828.

Van Paassen, L. A., R. Ghose, T. J. M. van der Linden, W. R. L. van der Star, and M. C. M. van Loosdrecht (2010), Quantifying biomediated ground improvement by ureolysis: Large-scale biogrout experiment, $J$. Geotech. Geoenviron. Eng., 136(12), 1721-1728, doi:10.1061/ (ASCE)GT.1943-5606.0000382.

Van Rijn, L. C. (1984), Sediment transport Part 1: Bed load transport, J. Hydraul. Eng., 110(10), 1431-1456.

Van Tittelboom, K., N. De Belie, W. De Muynck, and W. Verstraete (2010), Use of bacteria to repair cracks in concrete, Cem. Concr. Res., 40, 157-166, doi:10.1016/j.cemconres.2009.08.025.

Verwey, E. J. W., and J. T. G. Overbeek (1948), Theory of the Stability of Lyophobic Colloids, Elsevier, Amsterdam.

Wan, J., T. K. Tokunaga, and C.-F. Tsang (1995), Bacterial sedimentation through a porous medium, Water Resour. Res., 31(7), 1627-1636.

Whiffin, V. S., L. A. van Paassen, and M. P. Harkes (2007), Microbial carbonate precipitation as a soil improvement technique, Geomicrobiol. J., 24(5), 417-423, doi:10.1080/01490450701436505.

Yao, K. M., M. T. Habibian, and C. R. O'Melia (1971), Water and waste water filtration: Concepts and applications, Environ. Sci. Technol., 5, 1105-1112.

Zimmermann, R., and I. Main (2004), Hydromechanical behaviour of fractured rocks, in Mechanics of Fluid-Saturated Rocks, edited by Y. Gueguen and M. Bouteca, pp. 363-422, Elsevier, London. 